\title{
Assessment of Cover Systems at the Grand Junction, Colorado, Uranium Mill Tailings Pile: 1987 Field Measurements
}
G. W. Gee
H. D. Freeman
M. D. Campbell
J. F. Cline

February 1989

Prepared for the U.S. Department of Energy under Contract DE-AC06-76RLO 1830

Pacific Northwest Laboratory Operated for the U.S. Department of Energy by Battelle Memorial Institute 


\title{
DISCLAIMER
}

This report was prepared as an account of work sponsored by an agency of the United States Government. Neither the United States Government nor any agency thereof, nor Battelle Memorial Institute, nor any or their employees, makes any warranty, expressed or implied, or assumes any legal liability or responsibility for the accuracy, completeness, or usefulness of any information, apparatus, product, or process disclosed, or represents that its use would not infringe privately owned rights. Reference herein to any specific commercial product, process, or service by trade name, trademark, manufacturer, or othenwise does not necessarily constitute or imply its endorsement, recommendation, or favoring by the United States Government or any agency thereot, or Battelle Memorial institute. The views and opinions of authors expressed herein do not necessarily state or reflect those of the United States Government or any agency thereof.

\author{
PACIFIC NORTHWEST LABORATORY \\ operated by \\ BATTELLE MEMORIAL INSTITUTE \\ for the \\ UNITED STATES DEPARTMENT OF ENERGY \\ under Contract DE-ACO6-76RLO 1830
}

\begin{tabular}{|c|c|}
\hline \multicolumn{2}{|c|}{ Printed in the United States of America } \\
\hline \multicolumn{2}{|c|}{ Available from } \\
\hline \multicolumn{2}{|c|}{ National Technical Information Service } \\
\hline \multicolumn{2}{|c|}{ United States Department of Commerce } \\
\hline \multicolumn{2}{|c|}{5285 Port Royal Road } \\
\hline \multicolumn{2}{|c|}{ Springfield, Virginia 22161} \\
\hline \multicolumn{2}{|c|}{ NIIS Price Codes } \\
\hline \multicolumn{2}{|c|}{ Mic rotiche $A 01$} \\
\hline \multicolumn{2}{|c|}{ Printed Copy } \\
\hline & Price \\
\hline Pages & codes \\
\hline $001-025$ & $\mathrm{~A} 02$ \\
\hline 026-050 & A03 \\
\hline $051-075$ & $A 04$ \\
\hline $076-100$ & A05 \\
\hline $101-125$ & $A 06$ \\
\hline $126-150$ & A07 \\
\hline $151-175$ & $A 08$ \\
\hline $176-200$ & A09 \\
\hline 201.225 & A10 \\
\hline $226-250$ & A11 \\
\hline $251-275$ & A12 \\
\hline $276-300$ & A13 \\
\hline
\end{tabular}


PNL-6762

UC -70

\section{ASSESSMENT OF COVER SYSTEMS AT THE GRAND JUNCTION, COLORADO, URANIUM MILL TAILINGS PILE: 1987 FIELD MEASUREMENTS}
G. W. Gee
M. D. Campbe11
H. D. Freeman
J. F. Cline

\section{February 1989}

Prepared for the U.S. Department of Energy under Contract DE-AC06-76RLO 1830 


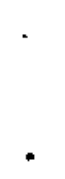




\section{EXECUTIVE SUMMARY}

Four Pacific Northwest Laboratory (PNL) scientists and a technician conducted an onsite evaluation of radon gas exhalation, water content profiles, and $\mathrm{plant}$ and animal intrusion for a series of cover systems located on the uranium mill tailings pile at Grand Junction, Colorado, between June 8 and $19,1987$.

The Grand Junction cover systems that were evaluated consisted of the following six test plots:

1. 1980 asphalt test (a 7 -cm-thick asphalt Tayer covered with soil ranging in thickness from $30 \mathrm{~cm}$ to $130 \mathrm{~cm}$ )

2. 1980 multilayer test (compacted soil or clay overlain with gravel and soil. The plots were divided into four, equalwidth strips with a $15-\mathrm{cm}$-thick layer of gravel covering the two middle strips)

3. 1981 earthen cover test (3-m-thick soil layers with four combinations of soil types and initial moisture distributions)

4. caissons (a sequence of seven cover treatments simitar in type to field tests but placed in buried, vertical containers)

5. 1981 asphalt test (a repeat of the 1980 test but having shallower soil cover, 30 to $40 \mathrm{~cm}$ thick)

6. 1981 multilayer (compacted clay/gravel mixtures overlain with gravel and soil, no surface gravel).

These six plots were sampled extensively down to the radon control layer (e.g., asphalt or wet clay) for soil moisture content and permeability. Radon gas emission through the surface was measured. Soil samples were collected and analyzed in the lab for particle-size distribution, particle density, bulk density, and ambient water content. Prairie dog burrows were excavated to discover the extent to which they penetrated the barriers. Plant type, density, and cover characteristics were measured. 
Radon flux measurements indicated that the asphalt cover systems performed more consistently in reducing radon levels than the other cover systems. Average radon flux levels were well below U.S. Environmenta] Protection Agency (EPA) guidelines $\left(20 \mathrm{pCi} \mathrm{m}^{-2} \mathrm{~s}^{-1}\right)$ for all asphalt test plots and were found to be near background ( 1 to $2 \mathrm{pCi} \mathrm{m}-2 \mathrm{~s}^{-1}$ ) on the oldest (1980) asphalt plots. The 1981 plots, except for two sampling points, also showed similarly low radon flux levels. Near-background levels also were found on the 1980 multilayer plots that had gravel at the surface and had no vegetation. Slightly higher values were found on the earthen cover (wet shale) plots. All other plots exhibited radon flux levels that approached or exceeded the EPA limits.

The soil used as a cover was similar on all test plots. Surface textures ranged from clay loams to silty clay loams containing 34 to $42 \%$ clay, with bulk densities ranging from 1.3 to $1.4 \mathrm{~g} \mathrm{~cm}^{-3}$ and average profile water contents (except for gravel covered surfaces) ranging from 6.0 to $8.0 \mathrm{wt} \%$. The corresponding soil water tensions were found to be in the range of 2.0 to $7.0 \mathrm{MPa}\left(7.1 \times 10^{4} \mathrm{~cm} \mathrm{H}_{2} \mathrm{O}\right)$. Such tension values are associated with soils that have been desiccated through water removal by desert plants. No water accumulation was observed with depth on any of the plots except those covered with grave1. On those plots the soil water tension values were near zero $(0.005 \mathrm{MPa})$ and the soil approached saturation. The plant cover appeared typical of semiarid sites (e.g., Colorado Plateau, eastern Utah, central Wyoming). No prairie dog burrows penetrated the barrier systems, and no burrows were found on the 1981 asphalt test plots. The soil cover on these plots may have been too shallow for prairie dogs, preventing them from burrowing to warmer soils below the winter frost line.

The data show that of all the covers tested, the asphalt cover performed the best at this site. These results suggest that a low-permeability asphalt layer constructed under field-scale conditions, with conventional equipment, can perform adequately for extended time. Although water infiltration studies for the asphalt were not conducted, the low radon diffusion rates suggest that asphalt also could work well as a water barrier. The soil 
moisture data of the surface cover also support the concept of a barrier that can maintain a low soil moisture profile for extended periods under semiarid conditions. 


\section{ACKNOWLEDGMENTS}

Soils maps for the Grand Junction area were obtained from the Soit Conservation Service. Pete Daniels and Steve Barger helped locate the source of the cover material. The Bureau of Reclamation climatologist provided monthly summary weather records covering the years from 1980 to 1987. The Agricultural Research Service loaned a Giddings Soil Probe for sampling the covers at the tailing site. United Nuclear Corporation (Grand Junction Office) provided orientation and access to their office and lab facilities, respectively, where we were allowed to dry our hundreds of soil samples and count radioactive gas emissions samples. The able assistance of L. D. Sant of Pacific Northwest Laboratory (PNL) during our stay in Grand Junction is acknowledged and appreciated. 



\section{CONTENTS}

EXECUTIVE SUMMARY .................. jii

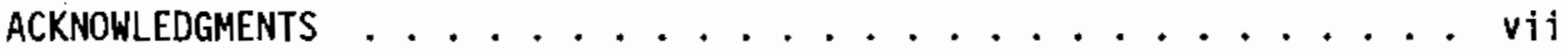

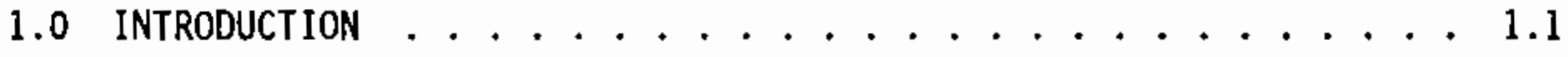

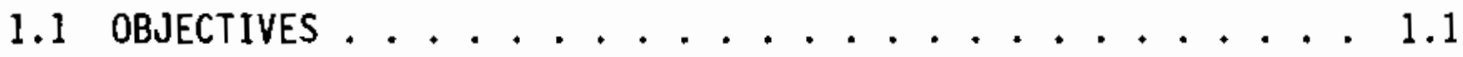

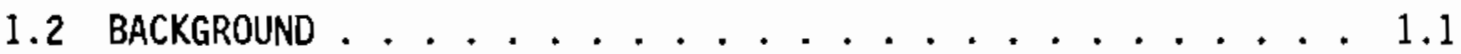

2.0 RADON FLUX MEASUREMENTS . . . . . . . . . . . 2.1

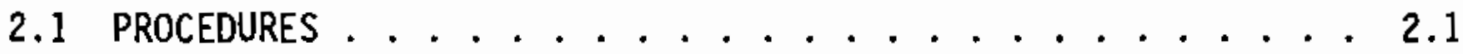

2.2 SAMPLING LOCATIONS . . . . . . . . . . 2.3

2.3 RESULTS . . . . . . . . . . . . 2.5

3.0 WATER BALANCE AND SOIL CDVER PROPERTIES . . . . . . . . . 3.1

3.1 ClimATE DATA . . . . . . . . . . . . . 3.1

3.2 SOIL COVER DATA . . . . . . . . . . . 3.1

4.0 BIOLOGICAL INTRUSION . . . . . . . . . . . . . 4.1

4.1 OBSERVATIONS OF PLANT SUCCESSION . . . . . . . . . 4.1

4.2 OBSERVATIONS OF PRAIRIE DOG INTRUSION $\ldots \ldots \ldots . \ldots . . \ldots$

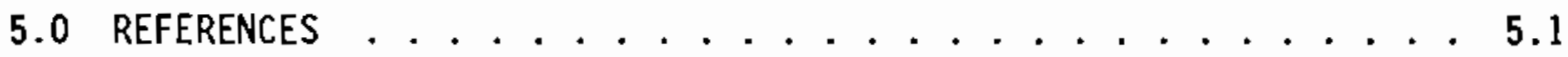

APPENDIX A - FIELD SURVEY OF GRAND JUNCTION TEST PLOTS . . . . . . A.1

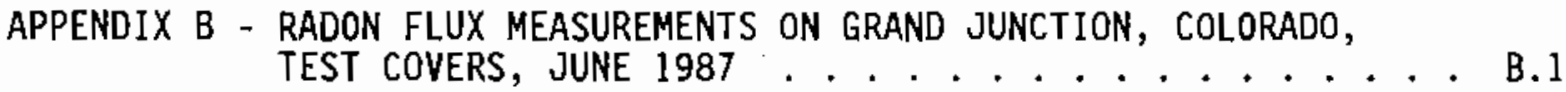

APPENDIX $c$ - CLIMATE SUMMARY ............... c.I

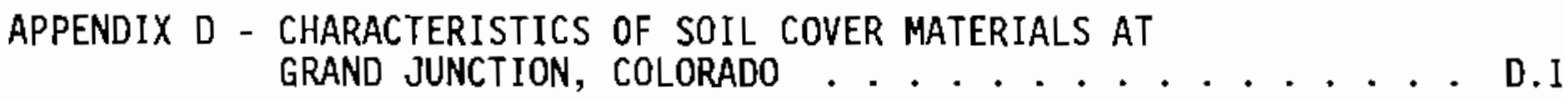




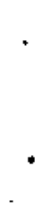




\section{FIGURES}

1.1 Schematic of the Three Major Cover Configurations Tested at

Grand Junction, Colorado . . . . . . . . . . . 1.2

I.2 Schematic Cross Section of Earthen and Multilayer Covers

Showing the Various Configurations Tested at Grand Junction,

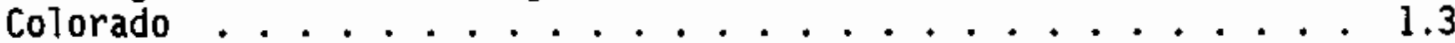

2.1 Large-Area Activated Carbon Collector Used for Radon

Monitoring at the Grand Junction Uranium Tailings

Pile, June 1987 . . . . . . . . . . . . . . . 2.2

2.2 Radon-Flux Sample Locations at the Grand Junction, Colorado,

Tailings PiTe . ................ 2.4

2.3 Average Radon Flux Levels for Covers Measured at the Grand Junction Uranium Tailings Pile, June 1987 . . . . . . . 2.9

2.4 Variation of Radon Flux with Time for Samples Taken from the 1980 Asphalt Cover Plots .............. 2. . . . . . . . .

2.5 Variation of Radon Flux with Time for Samples Taken from the 1981 Asphalt Cover Plots . . . . . . . . . . . . 2.11

2.6 Variation of Radon Flux with Time for Samples Taken from the 1981 Earthen Cover Plots . . . . . . . . . . . . 2.12

3.1 Water Retention Characteristics of Cover Soil Material at Grand Junction Uranium Tailings Pile . . . . . . . . . . 3.2

3.2 Water Content Profiles for 1980 Asphalt Test Plot . . . . . . . 3.4

3.3 Water Content Profiles for 1981 Asphalt Test Plot . . . . . . . 3.4

3.4 Water Content Profiles of 1981 Earthen Cover Plots . . . . . . 3.5

3.5 Average Water Content Profile of Caisson Soil Cover . . . . . 3.5

3.6 Water Content Profiles of 1980 Multilayer Plots . . . . . . 3.6

3.7 Water Content Profile of 1981 Multilayer Plots . . . . . . . 3.6

A.1 Survey Map of 1980 and 1981 Test Plots at Grand Junction Tailings Pile.................... A.2 


\section{TABLES}

2.1 Summary of Radon Flux Measurements Made on Radon Barriers at

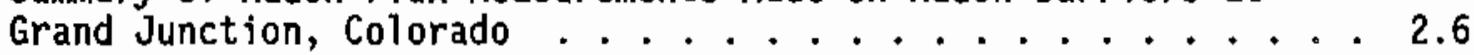

4.1 Percentage Vegetative Cover on Grand Junction Cover PTots . . . 4.2

4.2 Prairie Dog Burrows Observed in the Various Engineered Barriers Placed Over the Uranium Tailings at Grand Junction, Colorado .................... 4.4

B.1 Radon Flux Measurements Made June 9-16, 1987, on Grand Junction

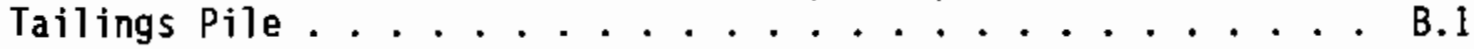

C.1 Precipitation for Grand Junction, Colorado ......... C.1

D.1 Grand Junction Radon Barrier Soils - Physical Characteristics...................... D.

D.2 Grand Junction Mi11 Tailings Pile Barriers Permeameter Test Results .................. D.2

D.3 Measurement Parameters Used to Compute Field Hydraul ic Conductivity on Grand Junction Test Plots ......... D.4 


\subsection{INTRODUCTION}

\subsection{OBJECTIVES}

The objectives of the 1987 field tests at Grand Junction, Colorado, were to 1) assess the continued performance of the barriers as measured by changes in surface radon flux, 2) evaluate the effect of plant and animal intrusion on protective covers, and 3 ) determine the long-term water storage of the covers.

\subsection{BACKGRDUND}

Cover tests were initiated by Pacific Northwest Laboratory (PNL) at Grand Junction, Colorado, during 1980 and 1981 to evaluate a variety of materials as radon barriers. Details of these tests are provided in PNL reports on the Uranium Mill Tailing Remedial Action Project (UMTRAP) (e.g., Hartley et a1. 1983).

Figures 1.1 and 1.2 show schematically the cover systems tested for radon gas control. These tests for radon gas control are described in detail in PNL reports (Hartley et a1. 1981, 1982, 1983; Gee et a1. 1981, 1982;

Hartley and Gee 1981; Freeman, Hartley, and Gee 1984). The earthen cover and multilayer systems shown in Figures 1.1 and 1.2 used local soil materials with the exception of the clay additive (bentonite) and alum that were used in the 1980 and 1981 multilayer tests. These materials were added in various combinations to the wetted clay/gravel layer that made up the radon control barrier. All other materials were obtained within $20 \mathrm{~km}$ of the tailings pile, in the vicinity of Grand Junction. Two borrow sites were used for the cover soil. One borrow site was located east-northeast of Grand Junction (about $15 \mathrm{~km}$ from the tailings pile). The second borrow area was located northwest of Grand Junction (about $14 \mathrm{~km}$ from the tailings pile). Based on local soil survey maps, the materials taken from these borrow areas are associated with two major soil types commonly found near Grand Junction: Billings silty clay loam and Ravola clay loam. In addition, Chipeta-Persayo shaley loam soils were also present at the second borrow site. Earlier reports (e.g., Gee et a1. 1981; Hartley et al. 1983) called these "adobe" 


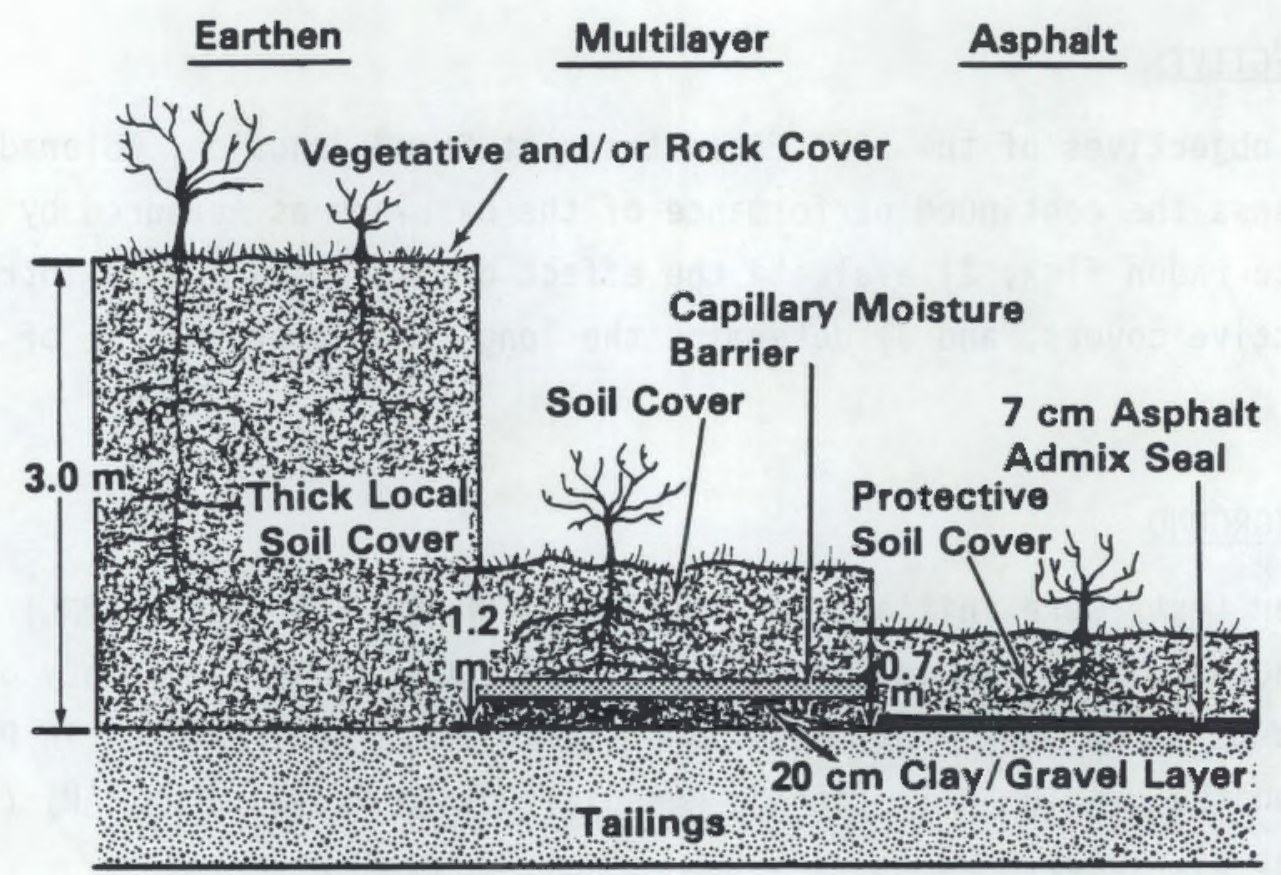

FIGURE 1.1. Schematic of the Three Major Cover Configurations Tested at Grand Junction, Colorado

soil, the local jargon for these types of soil materials. These materials were hauled and spread on the surface of all cover treatments. There were surprisingly small variations in soil properties over the site, and although the textures ranged from silty clay loam to clay, most of the samples tested had a clay loam texture and will be referred to throughout the text as a "clay loam" cover soil.

One of the unique features of these tests is the evaluation of asphalt as a low-permeability, radon control layer. Radon-222 has a half-life of 3.8 days; thus, controlling the rate of diffusion of radon from the tailings with a low-permeability layer in the cover system will limit its exhalation rate (through the decay process). This concept is utilized in all of the radon barrier designs. The effectiveness of asphalt as a radon control barrier results from the low porosity (nearly zero) that can be achieved with asphalt emulsion mixtures. Laboratory results indicated that very low gas diffusion coefficients could be achieved using asphalt emulsion admixed into 


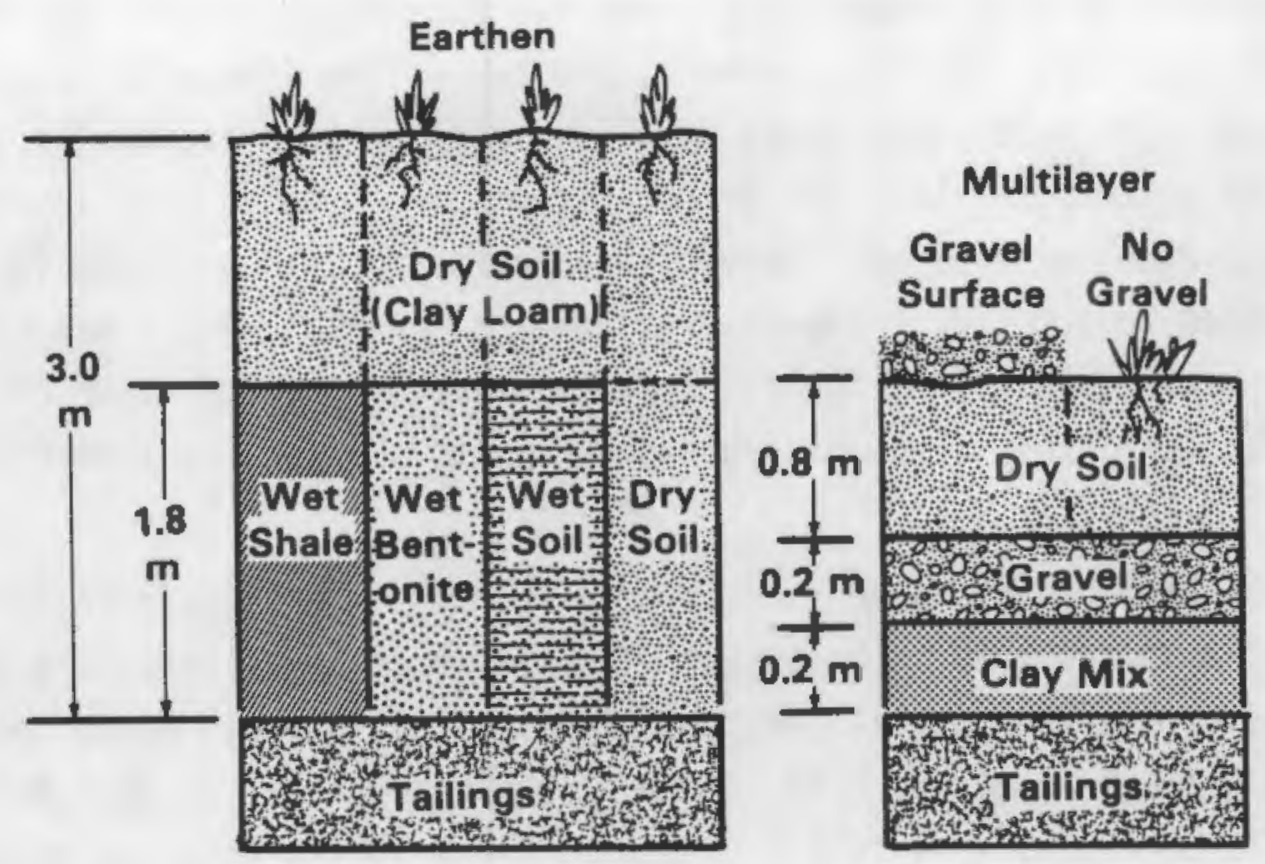

FIGURE 1.2. Schematic Cross Section of Earthen and Multilayer Covers Showing the Various Configurations Tested At Grand Junction, Colorado

sand and compacted (Baker et al. 1984). However, it should be recognized that any low-permeability material could be used as long as it is stable in the tailings environment and the cost isn't prohibitive. Asphalt was shown to be effective in radon control in laboratory tests and proved to be cost effective in the field (Baker et a1. 1982, 1984.)

The asphalt layer tests conducted previously at Grand Junction were designed to assess the use of paving technology (asphalt emulsions, cold-mix pavers, etc.) for covering tailing piles. The 1980 and 1981 asphalt barriers were installed by using a cold-mix paver to construct a layer of asphaltadmix (about $7 \mathrm{~cm}$ thick) containing $22 \mathrm{wt} \%$ asphalt on bare tailings and then covering the asphalt with pit-run soil materials. The thickness of the soil cover ranged from about 30 to $130 \mathrm{~cm}$ on the 1980 plots (Hartley et al. 1983). The soil cover over the asphalt protected the asphalt layer from ultraviolet degradation, thus greatly extending its lifetime. 
The earthen cover tests were designed to evaluate the effectiveness of local soil materials in controlling radon gas exhalation and to show the effects of soil type, moisture content, and compaction (porosity) on radon gas control. The multilayer tests were initiated to test the use of the inner cover systems and test the effectiveness of compacted clay layers in controlling radon exhalation. Conventional earth-moving equipment (dump trucks, sheep-foot rollers, smooth drum rollers, patrols, etc.) was used to apply the earthen materials for all cover systems. The clay layer required a portable pug-mill to mix the clay/gravel admix to appropriate specifications (Gee et a1. 1981).

The cover plots occupied a total of 1.93 ha of the surface of the tailings pile, with the 1980 asphalt test; the 1980 multilayer test; the 1981 asphalt test; the 1981 multilayer test; and the 1981 earthen cover test occupying $0.59,0.24,0.45,0.42$, and 0.23 ha, respectively. (See Appendix A for details of the plot layouts.) The plots were sufficiently large that earth-moving and paving equipment could be used easily. Monitoring points (for radon gas) were established on each plot and these monitoring points were maintained (except for the 1980 multilayer gravel-covered plots) throughout the course of the 7-year test period. On the 1980 multilayer plot, the surface gravel addition required reestablishment of monitoring points. These sampling locations are described in Section 2.0.

In June 1987 four PNL scientists and a technician visited the Grand Junction tailings pile and measured radon flux and soil moisture on the 1980 and 1981 cover plots. This report describes the results. A summary of radon flux data for all sites tested is provided in Section 2.0. Comparisons of radon control by asphalt, earthen, and multilayer cover systems are provided. Section 3.0 describes the climate (precipitation) during the 7 -year test period and the soil water conditions on all the cover treatments. Section 4.0 describes biointrusions (plant and animals) on the test plots, and Section 5.0 provides the references. Detailed data sets are presented in the appendices. 


\subsection{RADON FLUX MEASUREMENTS}

Radon flux measurements were made on the 1980 and 1981 radon barriers (asphalt, earthen cover, and multilayer systems). By comparing the 1987 measurements to data obtained previously (from 1981 to 1985), the integrity (as evidenced by the observed radon flux levels) of the cover systems can be determined.

\subsection{PROCEDURES}

Radon flux was measured by using 35 passive, 25 -cm-diameter activatedcarbon collectors (Figure 2.1). These collectors were developed by PNL for use by the U.S. Environmental Protection Agency (EPA) to measure radon release from phosphogypsum piles (Hartley and Freeman 1985). The technique relies on the sorption of radon by activated carbon at ambient temperatures. The amount of radon adsorbed on the charcoal is quantified by sealing the charcoal in an airtight container, allowing the daughters to equilibrate with the radon, and then counting the gamma activity from the ${ }^{214} \mathrm{Bi} 609 \mathrm{keV}$ peak. This activity, along with exposure and counting delay times, is used to calculate the radon flux from the measured surface.

The collector, which holds the activated carbon, consists of a polyvinyl chloride (PVC) end cap, spacer pads, charcoal distribution grid, a retainer pad with screen, and a steel retainer spring (Figure 2.1). Approximately $170 \mathrm{~g}$ of activated carbon are spread in the distribution grid and held in place with a retainer pad secured with a steel spring.

The collectors are deployed by firmly twisting the end cap into the surface being measured. The location and time of deployment is recorded in a notebook. After $\sim 24 \mathrm{~h}$ of exposure, the collectors are retrieved and the time recorded in the notebook. The activated carbon is removed from the collector and dumped through a large funnel into a $10-\mathrm{cm}$-diameter $\times 6.5$-cm-high plastic container, which is sealed with an air-tight lid. The radon is allowed to equilibrate for $4 \mathrm{~h}$ before counting to allow the ingrowth of radon daughters.

The amount of radon collected on the carbon is determined by gamma spectroscopy. The gamma spectroscopy system used for this study consisted of a 

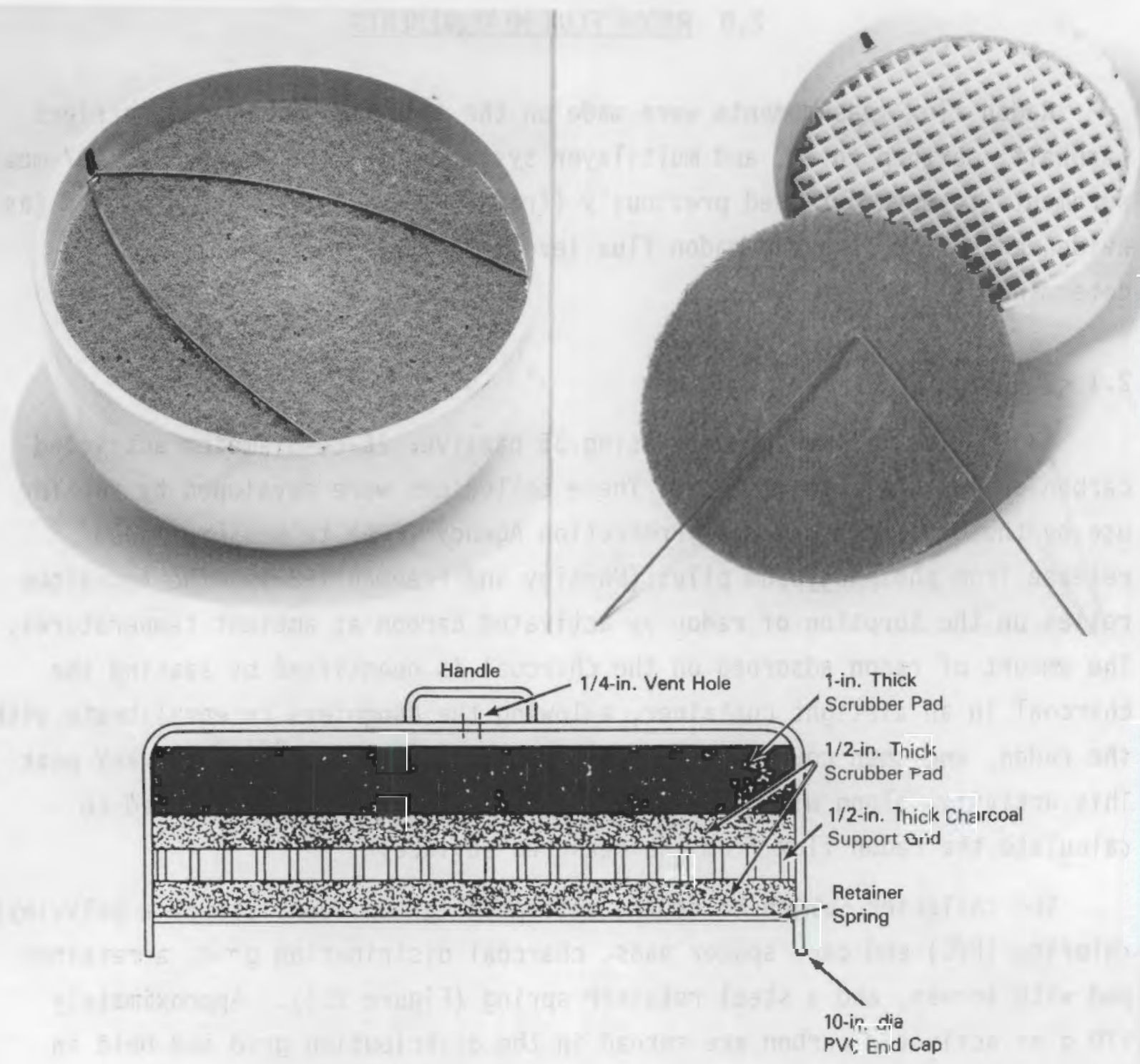

FIGURE 2.1. Large-Area Activated Carbon Collector Used for Radon Monitoring at the Grand Junction Uranium Tailings Pile, June 1987 
$7.6 \times 7.6 \mathrm{~cm} \mathrm{NaI}(\mathrm{T} 1)$ crystal, photomultiplier tube, amplifier, and portable multichannel analyzer. The $609-\mathrm{keV}$ peak of ${ }^{214} \mathrm{Bi}$ is used to quantify the radon on the charcoal. A National Bureau of Standards (NBS) traceable standard of ${ }^{226} \mathrm{Ra}$ sorbed on $170 \mathrm{~g}$ of carbon sealed in a plastic container is used to determine the counting system efficiency on a daily basis. A container of unexposed carbon obtained from the batch of carbon used to load the collectors is counted each day to determine if the carbon is contaminated with radon from ambient air or previous use.

The radon flux is calculated from the net counts using the following equation:

$$
J=\frac{c \lambda^{2}}{E \times A \times 0.037 \times\left(1-e^{-\lambda t_{1}}\right) \times\left[e^{-\lambda\left(t_{2}-t_{1}\right)}-e^{-\lambda\left(t_{3}-t_{1}\right)}\right]}
$$

$$
\text { where } \quad \begin{aligned}
\mathrm{J} & =\text { radon flux, } \mathrm{pCi} \mathrm{m}^{-2} \mathrm{~s}^{-1} \\
\mathrm{C} & =\text { net counts in } 609-\mathrm{keV} \text { peak } \\
\lambda & =\text { decay constant for radon, } 2.1 \times 10^{-6} \mathrm{~s}^{-1} \\
\mathrm{E} & =\text { counting system efficiency, } \mathrm{c} / \mathrm{d} \text {, where } \mathrm{d}=\text { disintegration } \\
\mathrm{A} & =\text { area of collector, } 0.052 \mathrm{~m}^{2} \\
0.037 & =\text { conversion from } \mathrm{d} / \mathrm{s} \text { to } \mathrm{pCi} \\
\mathrm{t}_{1} & =\text { exposure time, } \mathrm{s} \\
\mathrm{t}_{2} & =\text { time from start of sampling to start of counting, } \mathrm{s} \\
t_{3} & =\text { time from start of sampling to end of counting, } \mathrm{s}
\end{aligned}
$$

\subsection{SAMPLING LOCATIONS}

Different radon covers were monitored, including the 1980 multilayer and asphalt barriers and 1981 multilayer, asphalt, and earthen barriers. The locations monitored are shown in Figure 2.2. Eight locations were selected for daily measurement on the 1980 and 1981 asphalt covers to monitor the daily change in flux during the course of the 8-day monitoring period. Similarly four locations were chosen for daily monitoring on the earthen 


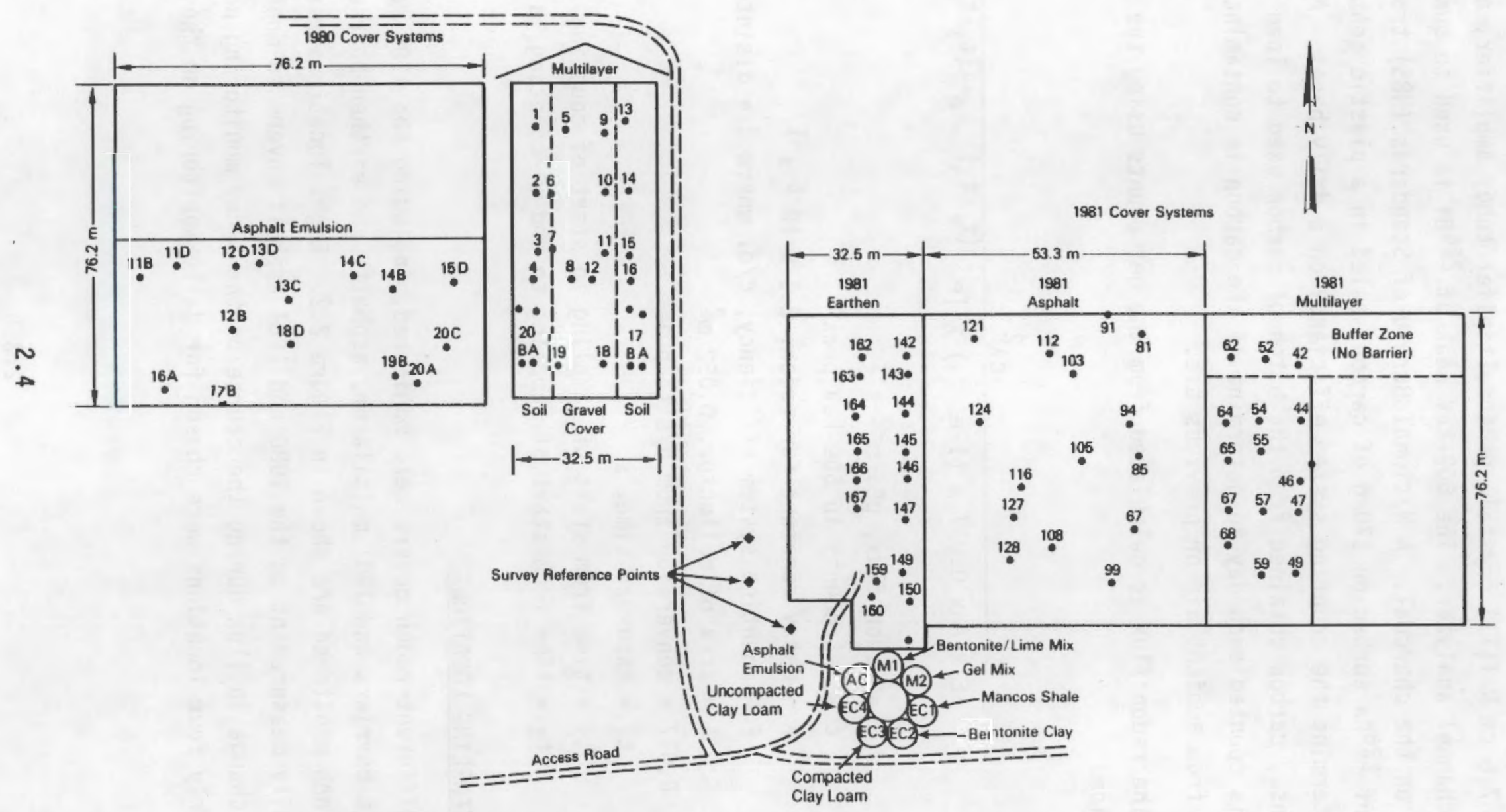

FIGURE 2.2. Radon-Flux Sample Locations at the Grand Junction, Colorado, Tailings Pile (scale as noted) 
covers, beginning with the third day of monitoring for a total of six measurements at each location. The remainder of the sampling locations were monitored for 2 days.

\subsection{RESULTS}

The results of the measurements are detailed in Table 2.1. A complete 1ist of data is presented in Appendix B. Figure 2.3 summarizes the radon flux data according to cover treatment. Figures 2.4, 2.5, and 2.6 show the relative variation in measured radon flux with time at selected sampling points for the 1980 asphalt, the 1981 asphalt, and the 1981 earthen cover plots, respectively. These data are comparable to those obtained by Karp (1986) and other investigators, suggesting that there are significant temporal variations of radon flux. However, for the course of the measurement, the average variation in radon flux over a period of 1 week was less than a factor of 2 for the earthen cover and asphalt plots tested. Temporal variations in radon flux are thought to be a result of barometric pressure changes, surface moisture variations, and possibly thermal effects, al though these changes were not documented during the test period. In any case, these variations, while real, do not affect the conclusions on the effectiveness of these covers.

The surface radon flux was below the EPA limit of $20 \mathrm{pCi} \mathrm{m}^{-2} \mathrm{~s}^{-1}$ for three of the cover treatments (earthen cover - wet shale, multilayer with surface gravel cover, and aspha1t). All other cover systems had radon flux levels that exceeded the EPA 1imit (USEPA 1983). Based on these observations, it appears that radon gas exhalation can be controlled to nearbackground levels only with asphalt, wet shale, or a multilayer system with gravel on the surface. Soil below the gravel was saturated, suggesting that significant water infiltration is occurring. If leaching of wastes from recharge events must be avoided, then a gravel cover system is not recommended. The wet shale earthen cover system continued to perform well as a barrier. There is some indication, however, that the shale is drying slowly. The water contents were considerably lower in the overburdened soils above the shale than in the shale. Under present climate conditions there is a net driving force that will slowly dry the shale, resulting in an increase in 
TABLE 2.1. Summary of Radon Flux Measurements Made on Radon Barriers at Grand Junction, Colorado

\begin{tabular}{|c|c|c|c|}
\hline \multirow[b]{2}{*}{$\underset{\text { ID }}{\text { Sample }}$} & \multirow[b]{2}{*}{$\begin{array}{c}\text { Number } \\
\text { of Points }\end{array}$} & \multicolumn{2}{|c|}{$\left(\mathrm{pCi} \mathrm{m}^{-2} \mathrm{~s}^{-1}\right)$} \\
\hline & & Average & $\begin{array}{l}\text { Standard } \\
\text { Deviation }\end{array}$ \\
\hline
\end{tabular}

$\begin{array}{llrr}11 \mathrm{~B} & 2 & 0.9 & 0.0 \\ 11 \mathrm{D} & 8 & 1.1 & 0.3 \\ 12 \mathrm{~B} & 2 & 1.4 & 0.0 \\ 12 \mathrm{D} & 2 & 1.0 & 0.4 \\ 13 \mathrm{~A} & 2 & 1.4 & 0.3 \\ 13 \mathrm{C} & 2 & 1.1 & 0.3 \\ 14 \mathrm{~B} & 2 & 1.3 & 0.1 \\ 14 \mathrm{C} & 8 & 1.4 & 0.5 \\ 15 \mathrm{D} & 2 & 1.3 & 0.4 \\ 16 \mathrm{~A} & 2 & 1.0 & 0.1 \\ 17 \mathrm{~B}(\mathrm{a}) & 2 & 115 . & 38.2 \\ 18 \mathrm{D} & 8 & 1.2 & 0.4 \\ 19 \mathrm{~B} & 2 & 1.0 & 0.1 \\ 20 \mathrm{~A} & 2 & 0.3 & 0.4 \\ 20 \mathrm{C} & 8 & 1.6 & 0.5\end{array}$

Treatment Average without 17B

1.2

0.3

$\begin{array}{ccrr}1980 \text { Multilayer } & \text { Barrier } & & \\ 01 & 2 & 35.2 & 13.0 \\ 02 & 2 & 16.1 & 3.5 \\ 03 & 2 & 65.0 & 11.1 \\ 04 & 2 & 102 . & 20.3 \\ 05-G & 4 & 2.7 & 1.1 \\ 06-G & 4 & 2.0 & 1.4 \\ 07-G & 4 & 2.4 & 1.0 \\ 08-G & 4 & 2.4 & 1.0 \\ 09-G & 4 & 2.4 & 1.6 \\ 10-G & 4 & 2.8 & 1.3 \\ 11-G & 4 & 1.6 & 1.5 \\ 12-G & 4 & 2.1 & 2.0 \\ 13 & 2 & 36.3 & 2.1 \\ 14 & 2 & 3.4 & 0.6 \\ 15 & 2 & 34.4 & 1.1 \\ 16 & 2 & 21.3 & 0.3 \\ 17 A & 2 & 53.8 & 56.1 \\ 17 B & 2 & 66.5 & 66.5\end{array}$

(a) 17B located at plot edge (not counted in average) 
TABLE 2.1. (contd)

\begin{tabular}{|c|c|c|c|}
\hline \multirow[b]{2}{*}{$\begin{array}{c}\text { Sample } \\
\text { ID } \\
\end{array}$} & \multirow[b]{2}{*}{$\begin{array}{r}\begin{array}{r}\text { Number } \\
\text { of Points }\end{array} \\
\end{array}$} & \multicolumn{2}{|c|}{$\left(\mathrm{pCi} \mathrm{m}^{-2} \mathrm{~s}^{-1}\right)$} \\
\hline & & Average & $\begin{array}{l}\text { Standard } \\
\text { Deviation }\end{array}$ \\
\hline $\begin{array}{l}18-G \\
19-G \\
20 A \\
20 B \\
21 A \\
21 B \\
22 A \\
22 B\end{array}$ & $\begin{array}{l}2 \\
2 \\
2 \\
2 \\
2 \\
2 \\
2 \\
2\end{array}$ & $\begin{array}{r}2.9 \\
2.8 \\
3.6 \\
110 . \\
7.4 \\
185 . \\
44.8 \\
2.6\end{array}$ & $\begin{array}{r}0.8 \\
1.0 \\
1.2 \\
17.3 \\
1.0 \\
71.3 \\
18.7 \\
0.4\end{array}$ \\
\hline
\end{tabular}

Treatment Average

Group (G) Cover

$3.5 \quad 0.4$

$\begin{array}{llll}\text { Average without Gravel } & 49.2 & 50.0 & 49.0\end{array}$

1981 Multilayer Barriers

$\begin{array}{lrrr}42 & 2 & 85.2 & 41.5 \\ 44 & 2 & 42.4 & 12.1 \\ 46 & 2 & 39.6 & 7.7 \\ 47 & 2 & 33.5 & 2.8 \\ 49 & 2 & 11.9 & 7.3 \\ 52 & 2 & 132 . & 6.6 \\ 54 & 2 & 74.5 & 22.6 \\ 55 & 2 & 106 . & 11.1 \\ 57 & 2 & 59.8 & 0.1 \\ 59 & 2 & 54.8 & 47.6 \\ 62 & 2 & 230.8 & 16.7 \\ 64 & 2 & 87.5 & 30.3 \\ 67 & 2 & 41.5 & 9.1 \\ 68 & 2 & 54.7 & 12.3 \\ 69 & 2 & 67.3 & 17.5 \\ & & & \\ \text { verage } & & 74.7 & 52.6\end{array}$

Treatment Average

1981 Asphalt Emulsion Barrier

$\begin{array}{rrrr}81 & 8 & 1.3 & 0.4 \\ 85 & 2 & 1.8 & 0.4 \\ 87 & 2 & 1.2 & 0.1 \\ 91 & 2 & 1.7 & 0.1 \\ 94 & 2 & 1.0 & 0.1 \\ 99 & 8 & 1.2 & 0.6 \\ 103 & 2 & 1.4 & 0.0\end{array}$


TABLE 2.1. (contd)

\begin{tabular}{ccccc}
$\begin{array}{c}\text { Sample } \\
\text { ID }\end{array}$ & $\begin{array}{c}\text { Number } \\
\text { of Points }\end{array}$ & & \multicolumn{2}{c}{$\left(\mathrm{pCi} \mathrm{m}^{-2} \mathrm{~s}^{-1}\right)$} \\
\cline { 1 - 2 } 105 & & $\frac{1}{\text { Average }}$ & $\begin{array}{c}\text { Standard } \\
\text { Deviation }\end{array}$ \\
108 & & 2 & 2.2 & 0.0 \\
112 & & 1.4 & 0.2 \\
116 & & 12.6 & 2.5 \\
121 & 8 & 1.6 & 0.6 \\
124 & 2 & 1.4 & 0.1 \\
127 & 2 & 5.0 & 1.8 \\
129 & 8 & 34.7 & 16.0 \\
Average & 2 & 1.6 & 0.6 \\
& - & & 4.7 & 8.8 \\
\hline
\end{tabular}

1981 Earthen Barriers

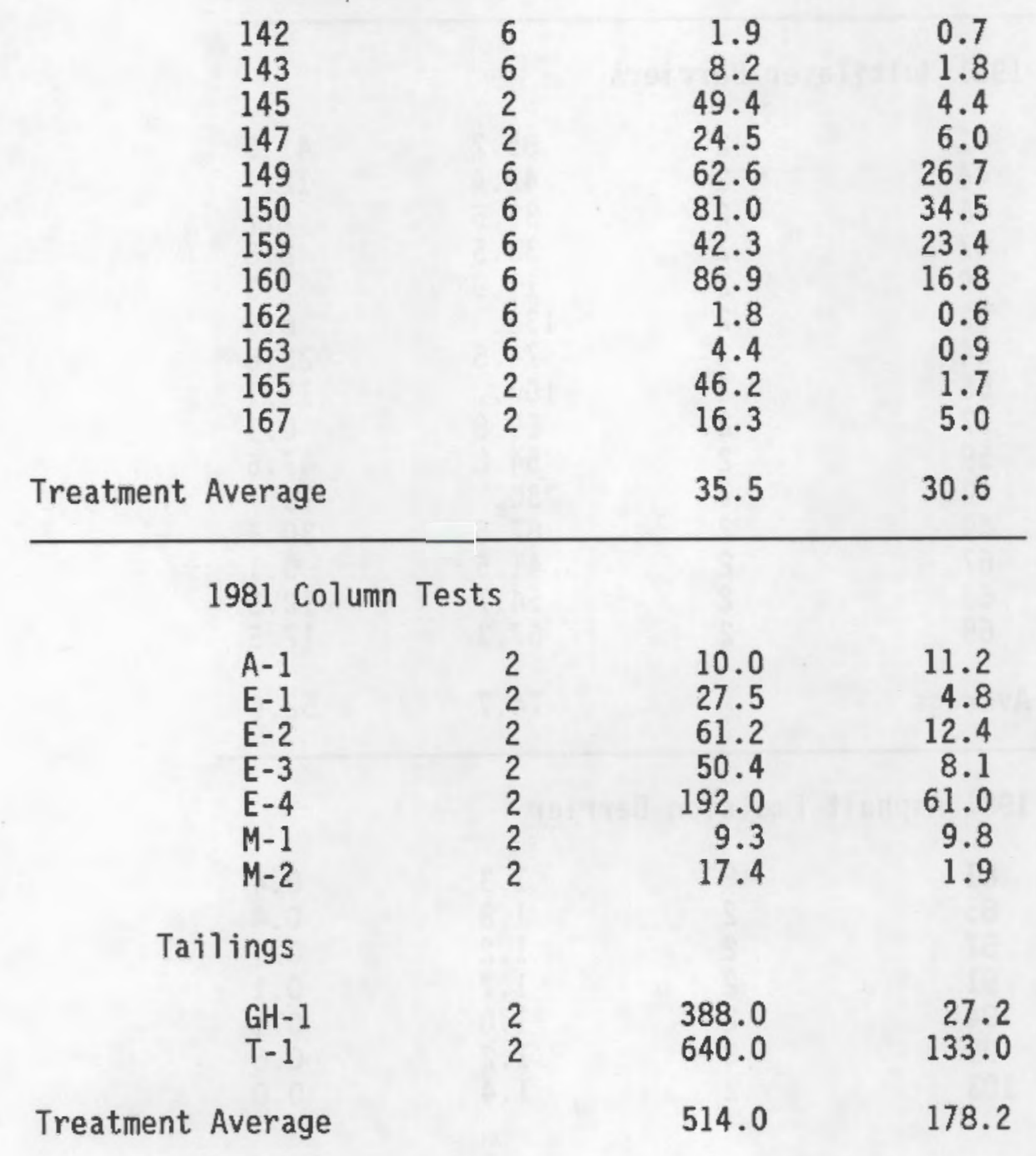




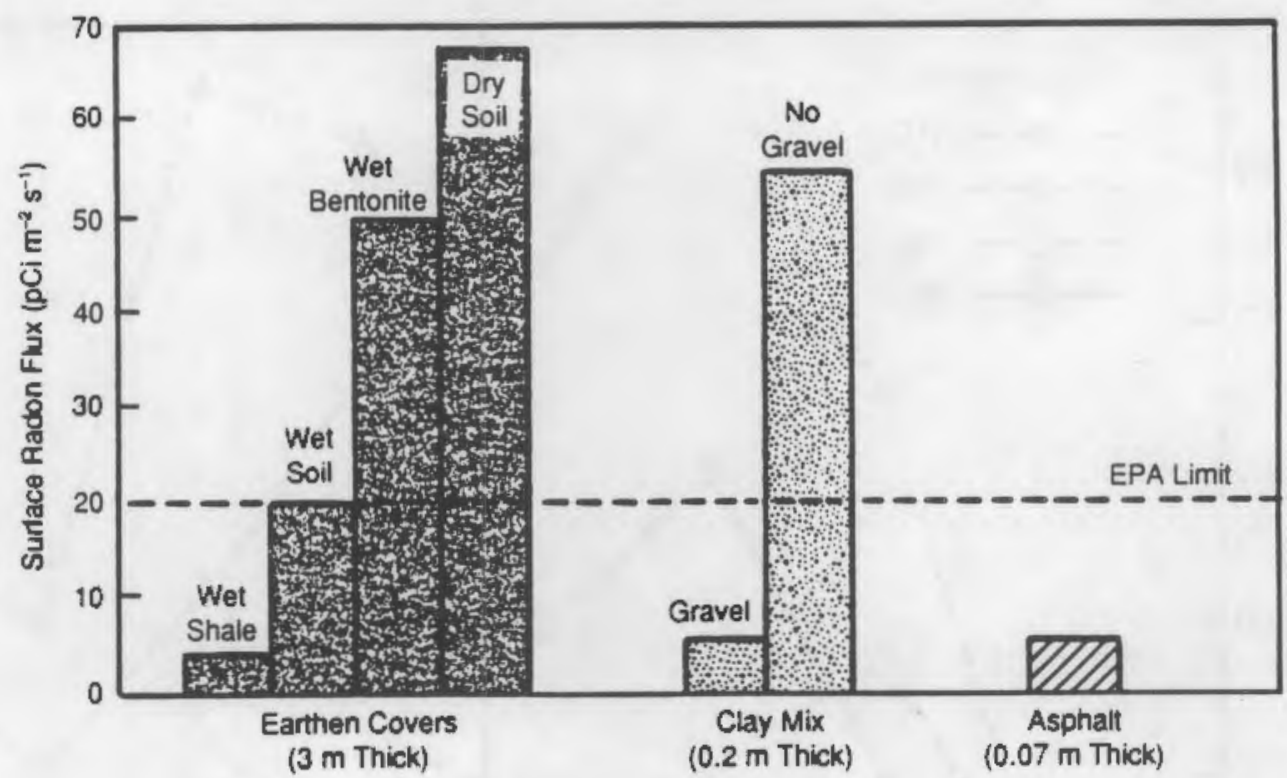

FIGURE 2.3. Average Radon Flux Leve1s for Covers Measured at the Grand Junction Uranium Tailings Pile, June 1987

radon flux. Continued monitoring of the test pile over the next several. years would be required to determine the extent of drying of the shale and assess the effect of drying on radon flux levels. Unfortunately, the tailings pile is scheduled to be moved within the next 2 years, so future monitoring is unlikely.

Based on the June 1987 observations, asphalt layers performed the best of all cover systems (1980 asphalt tests had the lowest overall average radon flux leve1). After 7 years the radon flux levels are comparable to those measured during the first year. These data suggest that the asphalt layer system would be an excellent candidate for testing as an alternate barrier system at Hanford. The Grand Junction tests have shown that field-scale asphalt layer systems can be constructed with conventional equipment to provide a long-lasting, low-permeability layer. 


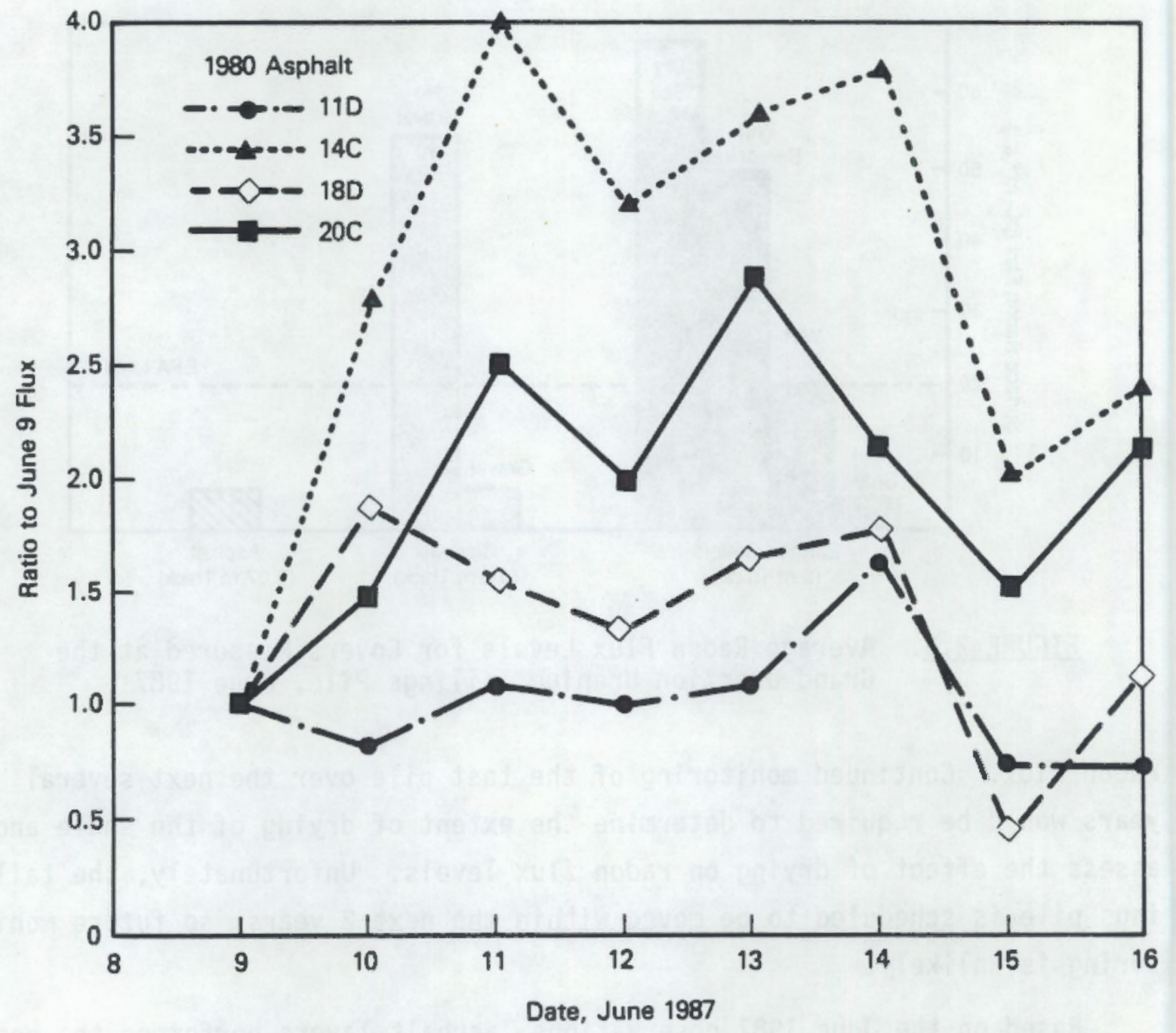

FIGURE 2.4. Variation of Radon Flux with Time for Samples Taken from the 1980 Asphalt Cover Plots (figure legends refer to sampling points) 


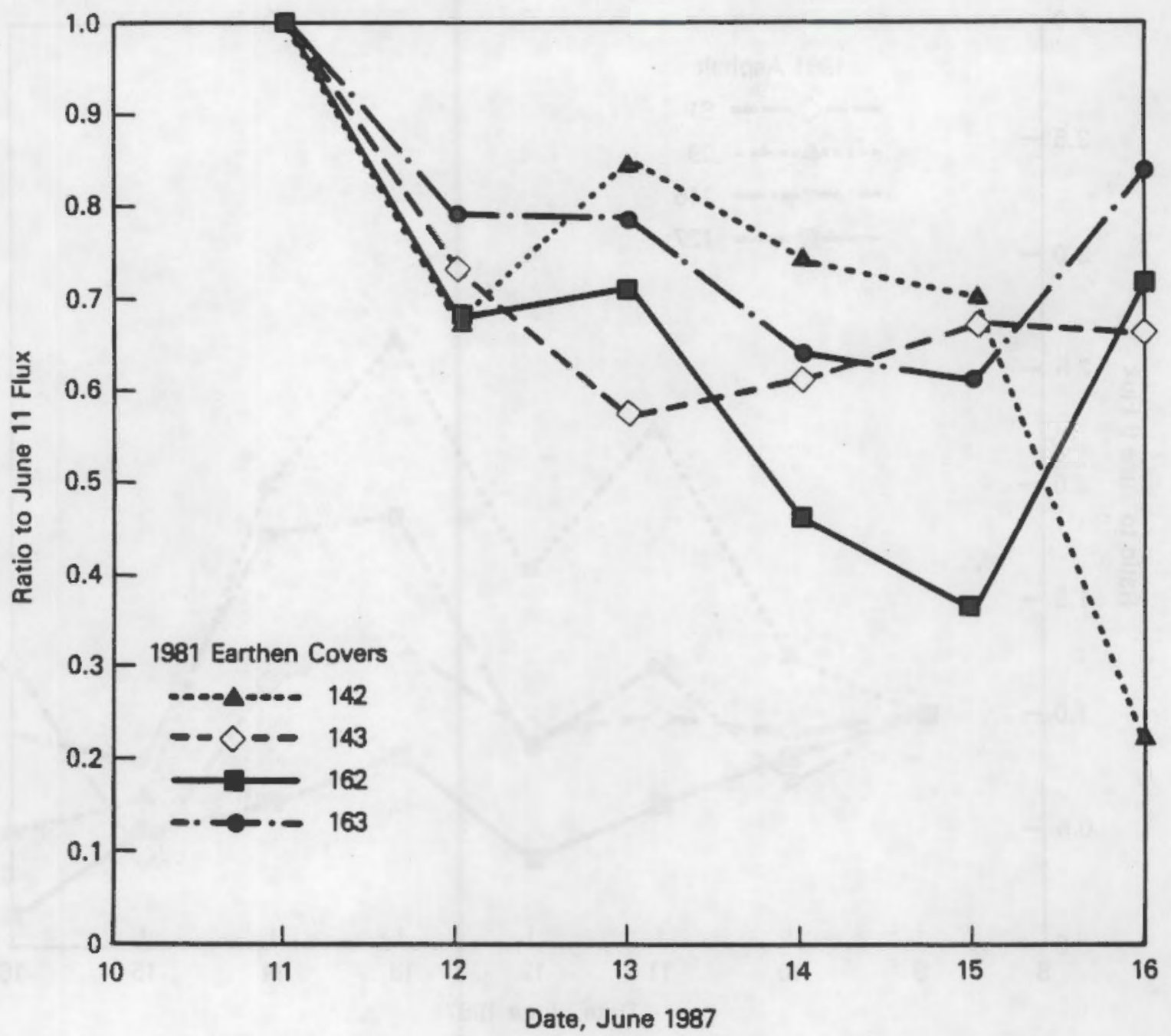

FIGURE 2.5. Variation of Radon Flux with Time for Samples Taken from the 1981 Asphalt Cover Plots (figure legends refer to sampling points) 


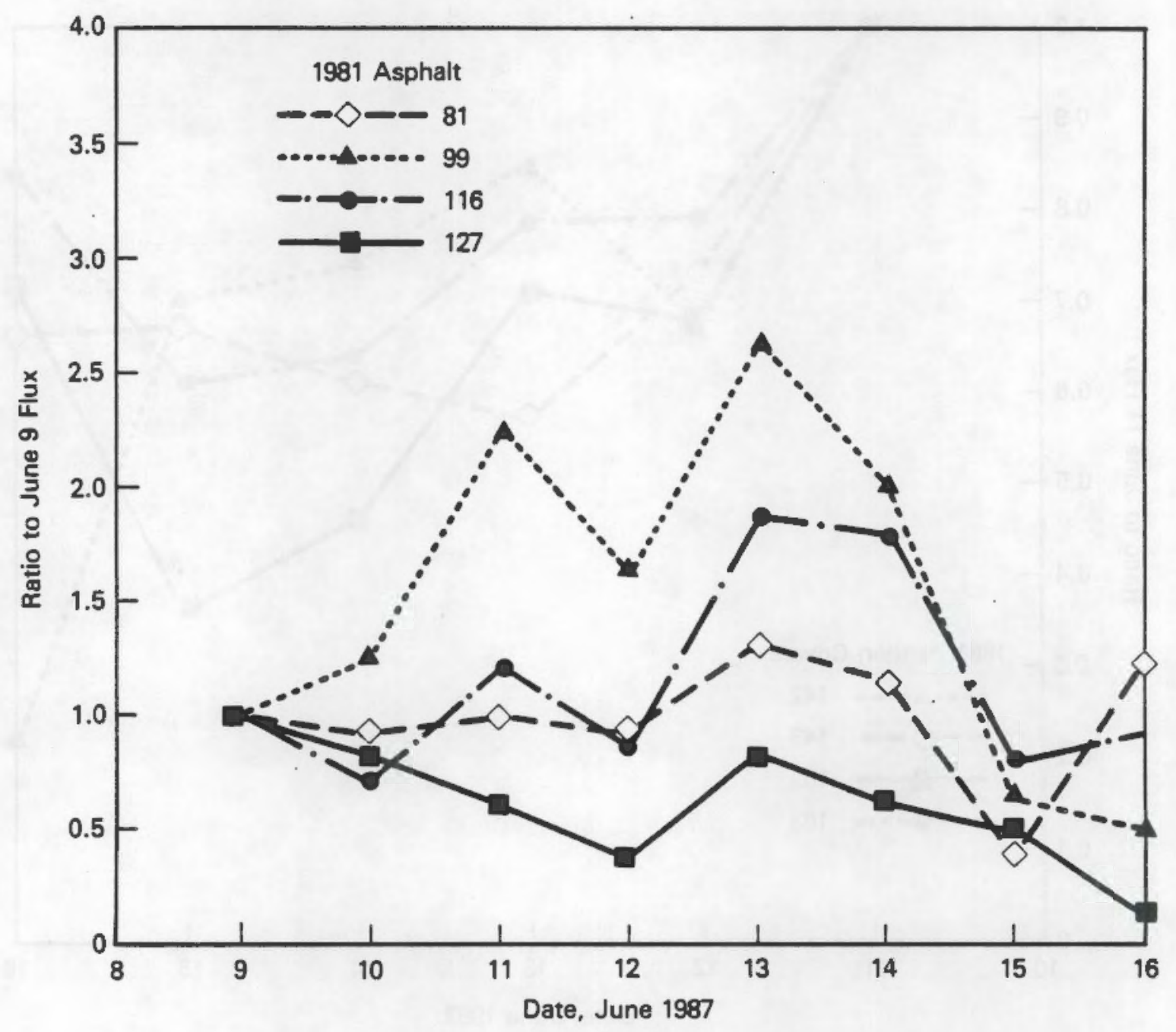

FIGURE 2.6. Variation of Radon Flux with Time for Samples Taken from the 1981 Earthen Cover Plots (figure legends refer to sampling points) 


\subsection{WATER BALANCE AND SOIL COVER PROPERTIES}

\subsection{CLIMATE DATA}

Climate data for Grand Junction were obtained from yearly summaries available from the National Oceanic and Atmospheric Administration (NOAA). The data for Grand Junction from June 1980 through May 1987 indicate that rainfall for this period was considerably above normal. All test years were above normal except for 1986, which had $19.3 \mathrm{~cm}$ compared to the long-term average of $20.3 \mathrm{~cm}$. The average annual precipitation for the 7 years (1980 through 1986) was $26.6 \mathrm{~cm}$, which was $131 \%$ of normal. Appendix C 1 ists the monthly precipitation averages for the period January 1980 through May 1987.

\subsection{SOIL COVER DATA}

Sampling of the soil cover for physical properties and soil water content profiles was undertaken during the same test period that radon gas samples were taken (June 9 through June 19, 1987). Soil samples were taken adjacent to areas where radon flux samples were taken. Water contents were determined gravimetrically from core samples collected with a Giddings-type (Giddings Corp., Ft. Collins, Colorado) hydraulic probe. This sampling allowed us to penetrate to the extent of the subsurface gravel or clay layers, thus obtaining water content profiles for the cover soil at all of the test locations. Water contents were determined by oven drying (ASTM-D2216-80, 1987). Water retention (capil1ary-pressure) characteristics were determined on laboratory samples using procedures described by ASTM (ASTM D2325-68, 1987). The water retention of soil material taken from the 1980 multilayer plot was also measured with a hanging water column (a modified version of the pressure plate method for measuring low soil water tensions).

Water retention (capillary pressure-water content) characteristics were determined for representative samples taken from each of the test plots. Figure 3.1 and Appendix Table D.1 show these characteristics for cover soil materials. Additional data for the dry end (i.e., tension greater than 


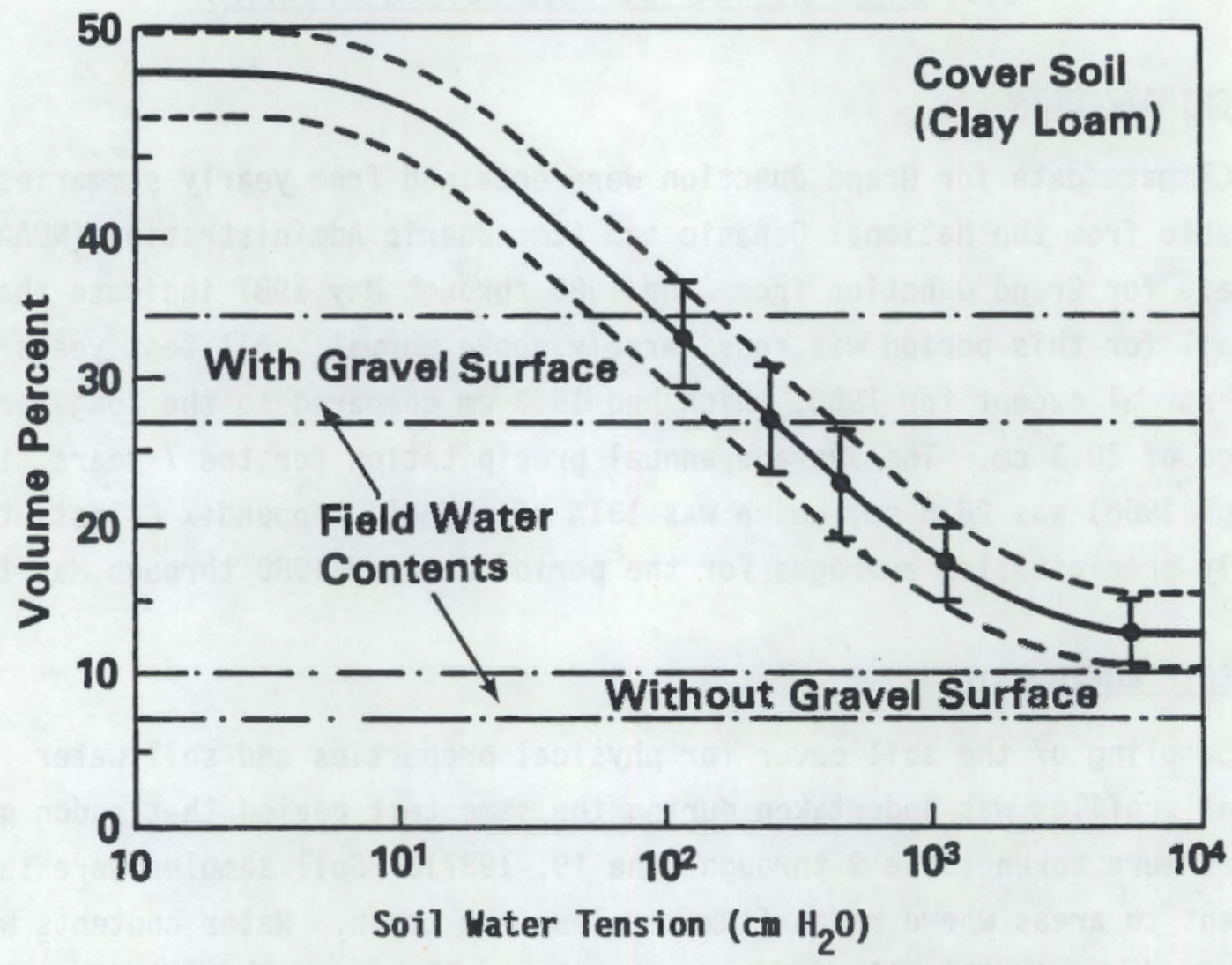

FIGURE 3.1. Water Retention Characteristics of Cover Soil Material at Grand Junction Uranium Tailings

Pile. (Dashed lines indicate ranges for field-measured water contents with and without gravel surfaces as noted)

$10^{4} \mathrm{~cm} \mathrm{H}_{2} \mathrm{O}$ ) were obtained by equilibrating soils at low water contents in storage jars in the laboratory and then using a Decagon $\mathrm{CX}-1$, dewpoint hygrometer (Decagon Devices Inc., Pullman, Washington) to measure the sample relative humidity or water activity. The soil water tension was then calculated using the equation:

$$
\tau=-0.459 T \ln (\mathrm{RH} / 100)
$$

where

$$
\begin{aligned}
\tau & =\text { soil water tension }(\mathrm{MPa}) \\
T & =\text { Kelvin temperature }(\mathrm{K}) \\
\mathrm{RH} & =\text { relative humidity. }
\end{aligned}
$$


Soil water tensions associated with field water contents ( 7 to 10 wt\%) in cover soils with no gravel on surface ranged from 2.0 to $7.0 \mathrm{MPa}\left(2 \times 10^{4}\right.$ to $\left.7 \times 10^{4} \mathrm{~cm} \mathrm{H}_{2} \mathrm{O}\right)$. Soils with gravel on the surface had observed water contents that ranged from 27 to $35 \mathrm{vol}$, with tensions ranging from 50 to $500 \mathrm{~cm}$ $\mathrm{H}_{2} \mathrm{O}$. These soil water tensions were confirmed by direct tensiometer measurements.

There was no direct way to determine if the subsurface gravel layer for these treatments was completely effective in preventing water infiltration. However, it is likely that the soil water tensions in the soils under the gravels were near zero (i.e., the soil approached saturation) some time during the 7-year test period and that drainage may have occurred. Based on the assumption that no drainage occurred and that lateral spreading has removed about $50 \%$ more stored water than is currently present, we can estimate that during the 7-year test period about $35 \mathrm{~cm}$ of additional water has been stored on the gravel-covered plots, as a result of the bare gravel surface. This amounts to almost two times the average annual precipitation. In contrast, on all other plots, the precipitation either ran off or was stored temporarily in the surface soil and was subsequently lost via evapotranspiration, because the initial moisture contents in the cover soils were not significantly different from those observed after 7 years.

Figures 3.2 through 3.7 show moisture profiles for each of the cover tests. For all but the 1980 multilayer plots (some of which had gravel on them), there is no evidence of water accumulation with depth. The asphalt barrier tests and the 1981 multilayer tests all show water contents in the range of 4 to $7 \mathrm{wt} \%$ ( 7 to 10 vol\%). For the 1980 multilayer test, where a 15-cm-thick layer gravel was placed in a center strip in the middle of the large test plot, there is ample evidence of significant water accumulation (Figure 3.6). Sampling under the gravel surface showed water contents that approached saturation, with tensions in the range of 50 to $300 \mathrm{~cm}$. The plots on either side of the gravel also were wetted above ambient conditions at depth by the effects of lateral spreading of water from the gravel surface treatment. 


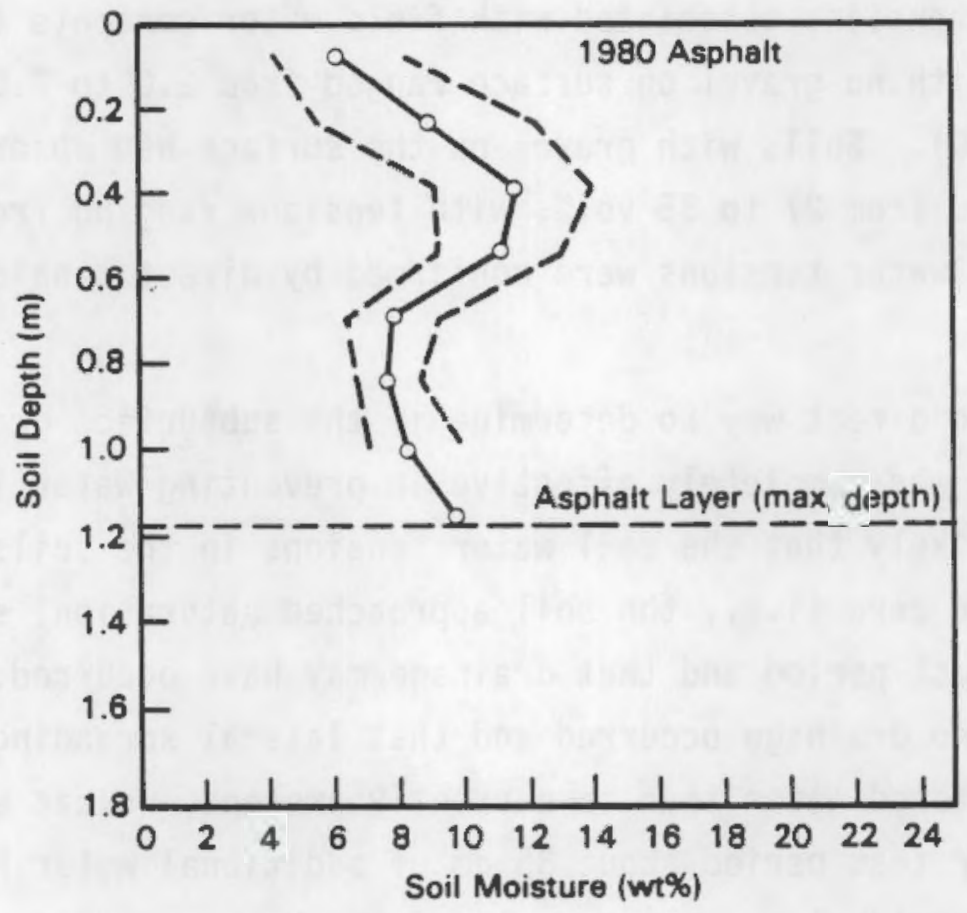

FIGURE 3.2. Water Content Profiles for 1980 Asphait Test Plot. Dashed lines represent confidence limits (one standard deviation).

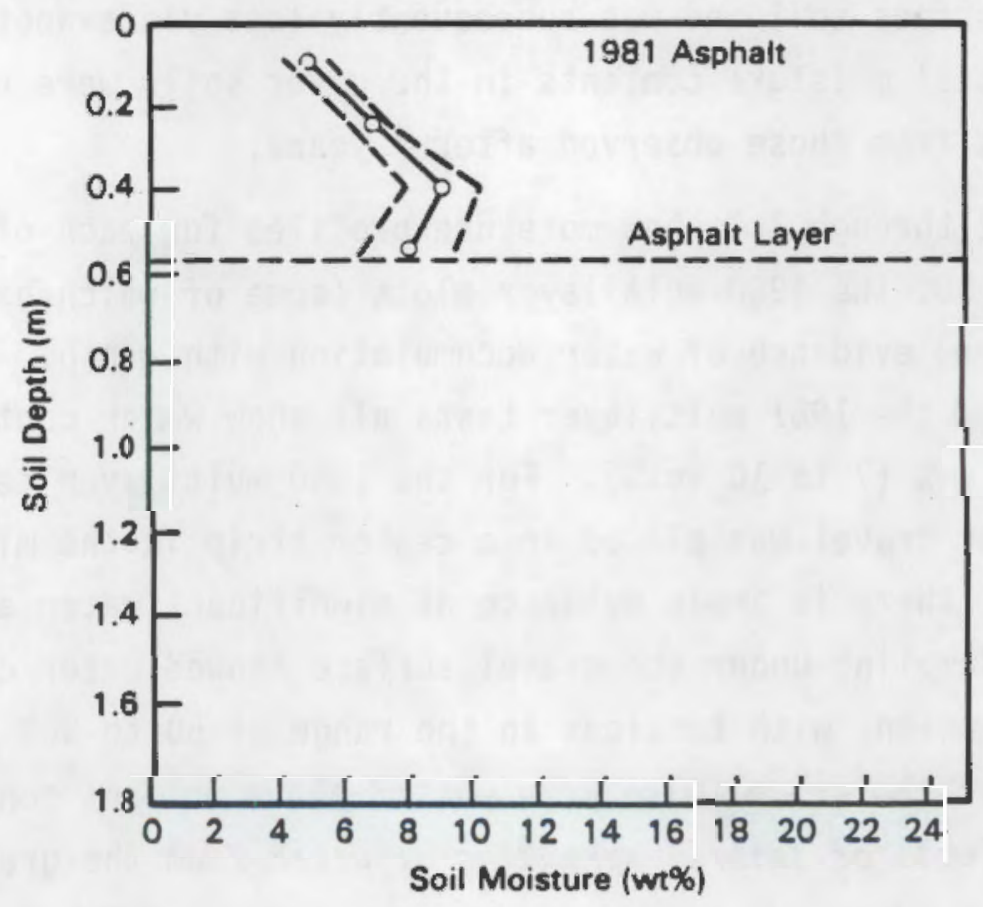

FIGURE 3.3. Water Content Profiles for 1981 Asphalt Test Plot. Dashed lines represent confidence limits (one standard deviation). 


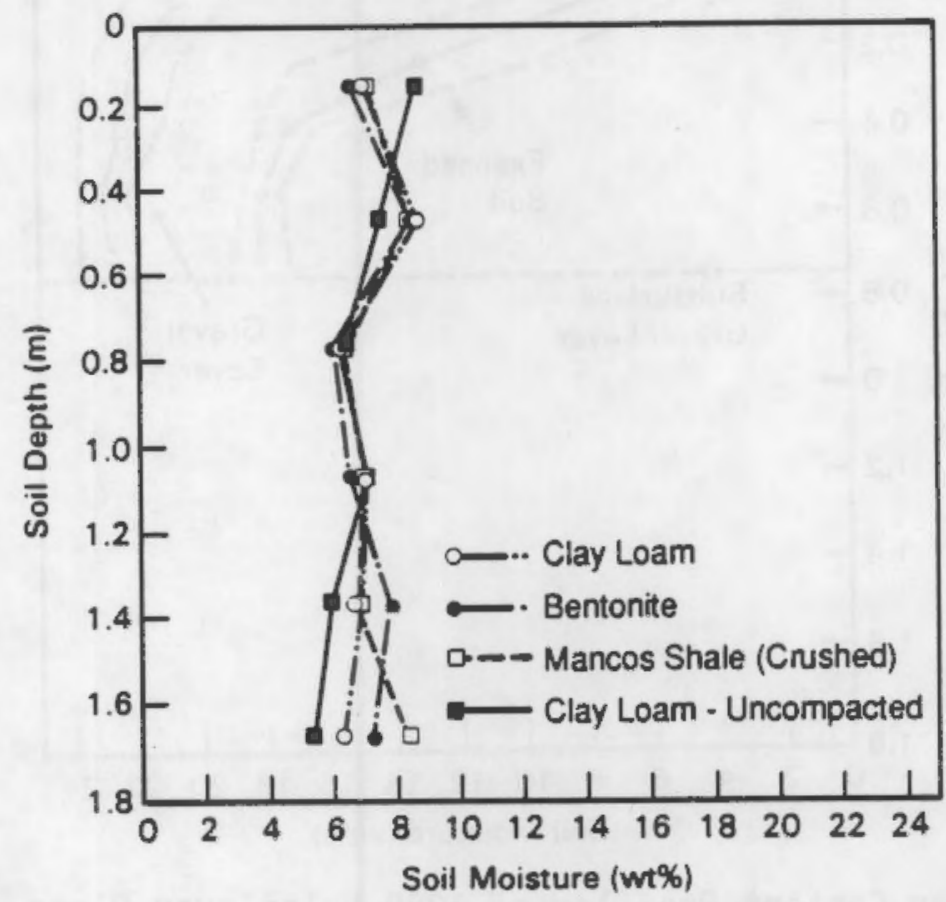

FIGURE 3.4. Water Content Profiles of 1981 Earthen Cover Plots

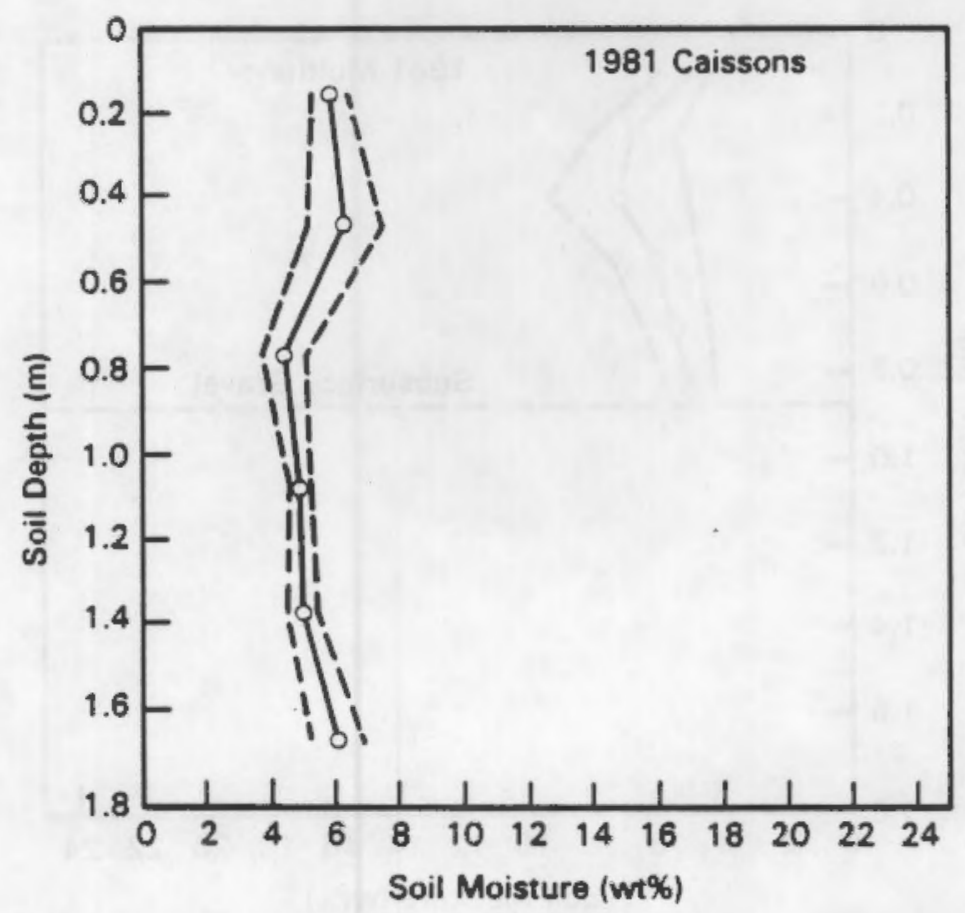

FIGURE 3.5. Average Water Content Profile of Caisson Soil Cover. Dashed lines represent one standard deviation. 


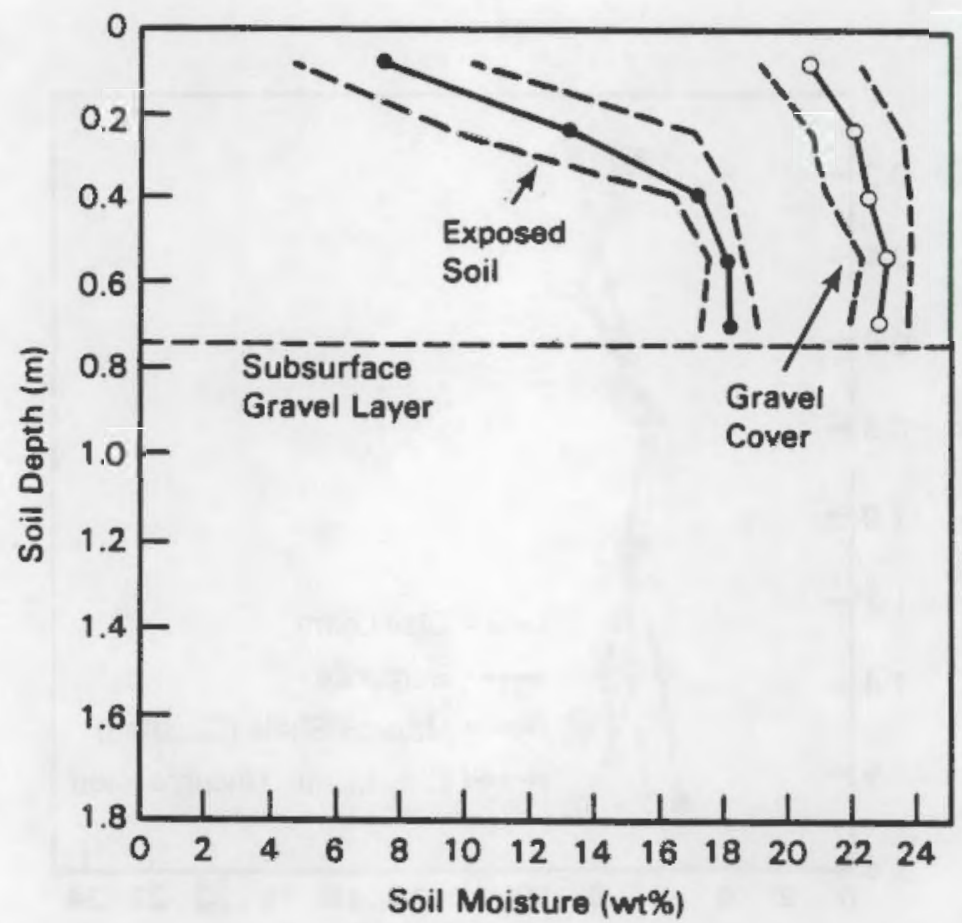

FIGURE 3.6. Water Content Profiles of 1980 Multilayer Plots. Dashed lines represent confidence limits (one standard deviation). The plot was constructed with a gravel cover in the middle of two types of exposed soil.

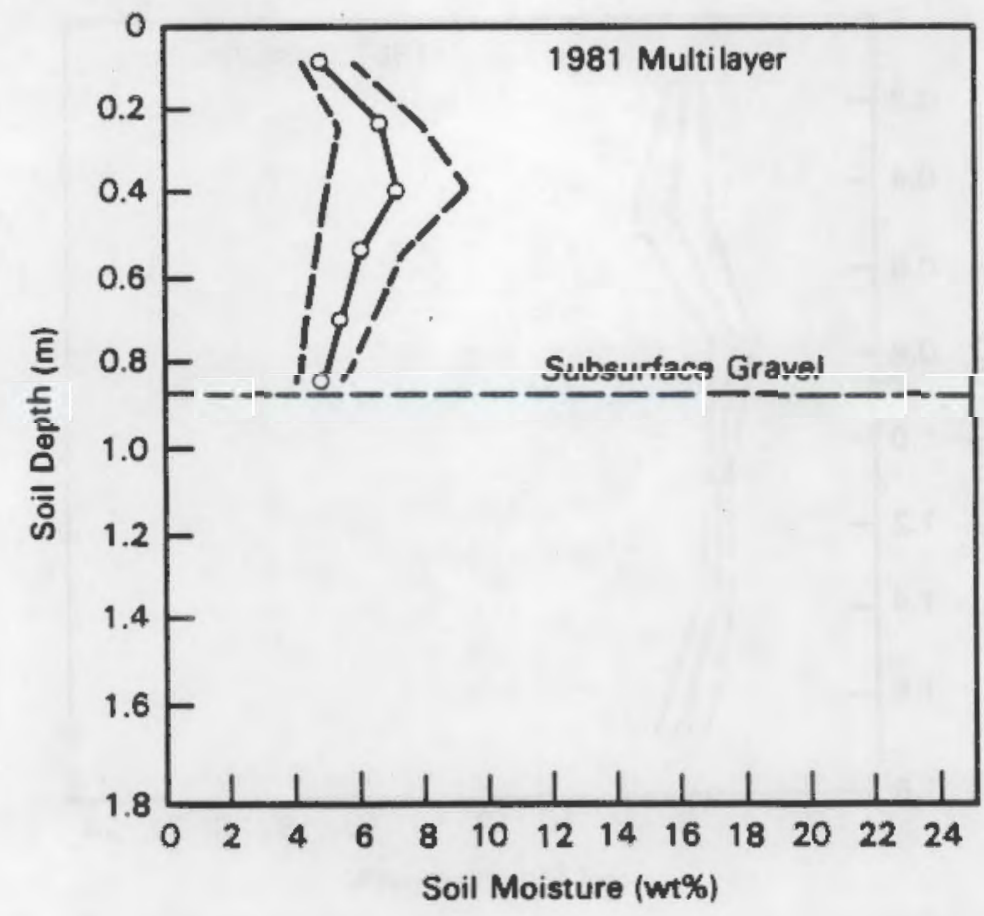

FIGURE 3.7. Water Content Profile of 1981 Multilayer Plots. Dashed lines represent confidence limits (one standard deviation). 
Hydraulic conductivity data were obtained on all of the test plots using a borehole test procedure (Reynolds and Elrick 1986). The hydraulic conductivity for all plots except the 1980 multilayer barrier plots ranged from $10^{-4}$ to $10^{-5} \mathrm{~cm} / \mathrm{s}$. Tables 0.2 and 0.3 list these measurements. Reynolds and Elrick report that the borehole procedure does not work well in wet, fine soils and is not recommended. Our preliminary test confirmed that the method was not suitable in wet clay loam soils. The data also suggest that highintensity rainstorms could cause runoff because the soil has such a low hydraulic conductivity. Runoff and rill erosion from the earthen cover plots have been observed during site visits over the past 7 years. 


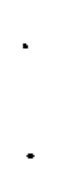




\subsection{BIOLOGICAL INTRUSION}

\subsection{OBSERVATIONS OF PLANT SUCCESSION}

During the June 1987 visit, we measured the percentage vegetative cover and plant species composition on barriers constructed in 1980 and 1981. Plots were covered with soil during the summers of 1980 and 198I; the 1980 plots were seeded and revegetated in the spring of 1981 . The 1981 plots were seeded in the fall of 1982. Seeding mixtures included grasses and forbs native to the area. Some invasion of other plant species a]so occurred. The percentage vegetative covers were measured using the Daubenmire (1959) method. The percentage vegetative cover within a $0.1-\mathrm{m}^{2}$ area was estimated. A quadrant measurement was made each meter along a 50-m tape. Five transect 1 ines were placed equidistant across each barrier type: 1980 multilayer, 1980 asphalt emulsion, 1981 multilayer, 1981 asphalt emulsion, and each earthen cover system (Mancos shale, bentonite clay, compacted clay loam, and uncompacted clay loam).

Results of the percentage vegetative cover are shown in Table 4.1. Annual grasses and forbs were the predominant vegetative cover on all barriers. Perennial grasses were found only on the 1980 asphalt emulsion test plot, because it was seeded to perennials and received supplemental irrigation in 1980.

The percentage vegetative cover on the 1980 multilayer plots was difficult to measure because approximately half of the plot was covered with a layer of gravel that eliminated plant growth (Kirkham, Beedlow, and Gee 1982). Therefore, the cover was measured only on the soil not covered with gravel. The $44 \%$ total cover found on nongravel surfaces of the 1980 multilayer plot was similar to the percentage cover on other barrier covers and control plots selected outside the uranium tailings site (Beedlow 1984). The total cover of $25 \%$ on the uncompacted adobe earthen cover was lowest of al 1 plots, because it was disturbed (excessive car and foot traffic) during the growing season. 
TABLE 4.1. Percentage Vegetative Cover on Grand Junction Cover Plots

\begin{tabular}{|c|c|c|c|c|c|}
\hline Seal Type & $\begin{array}{l}\text { Perennial } \\
\text { Grasses } \\
\end{array}$ & $\begin{array}{l}\text { Annual } \\
\text { Grasses }\end{array}$ & Shrubs & Forbs & Total \\
\hline 1980 Muttilayer & 0.0 & 19.7 & 1.7 & 22.3 & 43.7 \\
\hline $\begin{array}{l}1980 \text { Asphalt } \\
\text { Emulsion }\end{array}$ & 3.5 & 7.7 & 3.9 & 32.3 & 47.4 \\
\hline 1981 Multilayer & 0.0 & 22.1 & 0.9 & 9.6 & 32.6 \\
\hline $\begin{array}{l}1981 \text { Asphalt } \\
\text { Emulsion }\end{array}$ & 0.0 & 30.4 & 0.2 & 9.6 & 40.2 \\
\hline Mancos Shate & 0.0 & 17.1 & 0.2 & 22.1 & 39.4 \\
\hline Bentonite Clay & 0.0 & 15.6 & 0.3 & 19.5 & 35.4 \\
\hline Compacted Clay Loam & 0.0 & 13.9 & 0.5 & 25.7 & 40.1 \\
\hline $\begin{array}{l}\text { Uncompacted Clay Loam } \\
\text { Control Sites }\end{array}$ & 0.0 & 10.2 & 0.0 & 14.5 & 24.7 \\
\hline Glenburg Sandy Loam & 9.6 & 36.3 & 2.9 & 3.0 & 51.3 \\
\hline Avaion Loam & 12.4 & 40.3 & 1.1 & 6.1 & 59.8 \\
\hline Fruita Loam & 4.7 & 28.5 & 1.1 & 6.8 & 41.1 \\
\hline $\begin{array}{l}\text { Billings Silty Clay } \\
\text { Loam }\end{array}$ & 1.0 & 7.1 & 21.1 & 2.5 & 29.2 \\
\hline
\end{tabular}

(a) After 8eedlow (1984).

The main difference in percentage cover and species composition on the control plots and the engineered plots (except the 1980 asphalt emulsion plots) was the presence of perennial grasses in the control plots. This phenomenon is characteristic in natural species succession on disturbed lands. The presence of perennial grasses on the 1980 asphalt emulsion plots shows plant succession can be speeded up by seeding and irrigation.

Fourteen plant species were observed on the cover plots. Annual plants were predominant on all barrier plots. The two perennial grasses (Agropyron 
cristabum and Sporobulus cryptandrus) occurred only on the 1980 asphalt emulsion plots. Early invader species, such as Russian thistle (Salsola kali), that occurred in 1980 and 1981 (Beedlow 1984) had nearly disappeared from the cover in 1987. This a] so shows the natural trend in plant succession on disturbed lands.

The high occurrence (95\% frequency) and cover (30\%) of the annual grass (Agropyron triticateum) on the asphalt emulsion 1981 plots were visually obvious. This high frequency of occurrence and percentage cover may have been caused by a wet soil condition during seed germination. This wet soil condition was probably caused by the 1 imited soil cover $(-0.3 \mathrm{~m})$ over the impervious asphalt emulsion layer. Nearly the same vegetative cover was observed at the edges of the gravel layer on the 1980 multilayer system and over the caissons containing representative cover systems, which had nearly $100 \%$ cover on the lysimeter cover containing the asphalt layer. On this caisson, the soil had settled to a level below the surrounding soil surface, forming a collection basin. Increased moisture accumulation because of snow entrapment and possible runon from adjacent sites accounted for increased cover.

\subsection{OBSERVATIONS OF PRAIRIE DOG INTRUSION}

Intrusion into the Grand Junction tailings by white-tailed prairie dogs (Cynomys leucurus) has been documented (Shuman and Whicker 1986). They found high radon flux values as a result of repeated intrusions through areas of thin cover material on the site. However, none of the observations by Shuman and Whicker were on any of the 1980 or 1981 test plots. Disturbance of the site by burrowing animals also can significantly alter radon release from the site.

The number of prairie dog burrows observed on the different barriers are shown in Table 4.2. The total area of each engineered barrier was surveyed for burrow entrances. Two different hole entrance placements were observed, one on the level and the other on the edges of the barrier covers. Mounds with steep edges were created when the barriers were covered with soil. Therefore, the number of hole entrances observed on the mound edges were 
IABLE 4.2. Prairie Dog Burrows Observed in the Various Engineered Barriers Placed over the Uranium Tailings at Grand Junction, Colorado

Engineered Barriers

1980 Multilayer

1980 Asphalt Emulsion

1981 Multilayer

1981 Asphait Emulsion

1981 Earthen Cover

- Mancos Shale

- Bentonite Clay

- Compacted C]ay Loam

- Uncompacted Clay Loam
Number of Holes
in Barriers

4

5

3

0

2

3

3

0
Number of Holes on Edges of Barriers
0

5

2

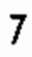

2

3

3

separated from entrances on the level part of the mound. The number of holes located on the level sections were similar on all engineered barriers except the 1981 asphalt emulsion plot and the uncompacted adobe plot. The apparent reason for no holes on the 1981 asphalt enulsion plots is that the $30-\mathrm{cm}$ thick soil over the asphalt layer was not enough soil depth to construct a burrow to withstand winter cold. All burrows with nests on other barriers were dug 0.6 to $0.8 \mathrm{~m}$ below the soil surface. The two burrow entries observed at the edge of the 1981 asphalt emulsion were abandoned. There was evidence that the prairie dogs do not Tike burrows over asphalt emulsion layers, because all the burrows on the 1980 asphalt emulsion plots were also abandoned, even though there was more than $0.6 \mathrm{~m}$ of soil over part of the emulsion. Also, none of the burrows (holes) that were excavated with a backhoe on these two plots reached the asphalt emulsion layer. The soil was shallower at the 1981 site than on any of the other soil covers and this may have discouraged animal penetration. It is also possible that asphalt emulsion vapors may have repelled the prairie dogs. 
The reason why no holes were dug on the level part of the uncompacted adobe was less evident, because there was enough soil depth for a satisfactory burrow. This plot and the area around the caissons were near excessive foot and auto traffic. These disturbances may have discouraged the prairie dogs from establishing burrows in this area. However, three inhabited burrows were observed on the edge of the mound.

No holes observed on any of the barriers penetrated into the uranium tailings. This is evidence that the depth of the soil cover and/or the asphalt emulsion layer or stone layer prevented the prairie dogs from digging into the uranium tailings that are below all of the barriers. However, burrow depths may be deeper in colder climates to keep nests below the frost leve]s. 

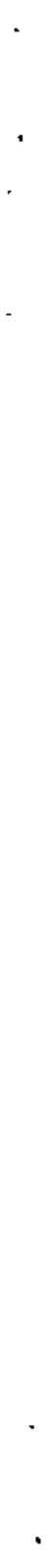


\subsection{REFERENCES}

ASTM-02325-68. 1987. Standard Test Method for Capillary-Moisture Relationships for Coarse- and Medium-Textures Soils by Porous-Plate Method. 1987 Annua 7 Book of ASTM Standards, Section 4, Vol. 04.08:363-369. ASTM, Philadelphia, Pennsylvania.

ASTM-D2216-80, 1987. Method for Laboratory Determination of Water (Moisture) Content of Soil, Rock and Soil-Aggregate Mixtures. 1987 Annual Book of ASTM Standards, Section 4, Vo7. 04.08:355-362. ASTM, Philadelphia, Pennsylvania.

Baker, E. G., H. D. Freeman, J. N. Hartiey, and G. W. Gee. 1982. "Cost and Effectiveness of Radon Barrier Systems." Proceedings of the Fifth Symposium on Uranium Mill Tail ings Management, Pp. 383-395. Civil Engineering Department, Colorado State University, Fort Collins, Cotorado.

Baker, E. G., J. N. Hartiey, H. D. Freeman, T. E. Gates, D. A. Ne1son, and R. L. Dunning. 1984. Asphait Emulsion Radon Barrier Systems for Uranium Mill Tailings--An Overview of the Technology. DOE/UMT-214. PNL-4840, Pacific Northwest Laboratory, Richland, Washington.

Beedlow, P. A. 1984. Revegetation and Rock Cover for Stabilization of Inactive Uranium Mill Tailings Disposal Sites: Final Report. DOE/UMT-0217. PNL-5105, Pacific Northwest Laboratory, Richland, Washington.

Daubenmire, R. 1959. "A Canopy Method of Revegetational Analyses." Northwest Sci. 33:43-64.

Freeman, H. D., J. N. Hartiey, and G. W. Gee. 1984. "Radon Barrier FieldTest Monitoring at Grand Junction Tailings Pile." In Proceedings of the Sixth Symposium on Uranium Mill Tailings Management, Pp. 277-286. Civil Engineering Department, Colorado State University, Fort Collins, Colorado.

Gee, G. W., J. T. Zellmer, M. E. Dodson, R. R. Kirkham, B. E. Opitz, D. R. Sherwood, and J. Tingey. 1981. "Radon Control by Multilayer Earth Barriers, 2. Field tests." In Proceedings of the Fourth Symposium on Uranium Mill Iail ings Management, pp. 289-308. Civil Engineering Department, Colorado State University, fort Collins, Colorado.

Hartley, J. N., and H. D. Freeman 1985. Radon Flux Measurements on Gardinier and Royster Phosphogypsum Piles Near Tampa and Mulberry. Florida. EPA 52015-85-029, U.S. Environmental Protection Agency, Eastern Environmental Radiation Facility, Montgomery, Alabama.

Hartley, J. N., and G. W. Gee. 1981. "Uranjum Mill Tailings Remedial Action (UMTRA) Joint Field Test." In Proceedings of the Fourth symposium on Uranium Mill Tail ings Management, pp. 115-134. CiviT Engineering Department, Colorado State University, Fort Collins, Colorado. 
Hartley, J. N., P. L. Koehmstedt, D. J. Esterl, H. D. Freeman, J. L. Buelt, D. A. Nelson, and M. R. Elmore. 1980. In Asphalt Emulsion Sealing of Uranium Mi11 Tailings 1979 Annual Report. PNL-3290, Pacific Northwest Laboratory, Richland, Washington.

Hartley, J. N., P. L. Koehmstedt, D. J. Esterl, H. D. Freeman, J. L. Buelt, D. A. Nelson, and M. R. Elmore, 1981. Asphalt Emulsion Sealing of Uranium Mi11 Tailings 1980 Annual Report. DOE/UMT-0201. PNL-3752, Pacific Northwest Laboratory, Richland, Washington.

Hartley, J. N., G. W. Gee, H. D. Freeman, J. F. Cline, P. A. Beediow, J. L. Buelt, J. R. Relyea, and T. Tamura. 1982. "Uranium Mill Tailings Remedial Action Project (UMTRAP) Cover and Liner Technology Development Project." IAEA-SM-262/39, PD. 429-448. In Proceedings of the International Symposium on Management of Wastes from Uranium Mining and Milling, Albuquerque, New Mexico.

Hartley, J. N., G. W. Gee, E. G. Baker, and H. D. Freeman. 1983. 1981 Radon Barrier Field Test at Grand Junction Uranium Mill Tailings Pile. DOE/UMT-0213. PNL-4539, Pacific Northwest Laboratory, Richland, Washington.

Karp, K. E. 1986. Covers Monitoring at the Grand Junction Tailing Pile: A Progress Report for the Period July 1985 Through September 1985. Report for UMTRA Project Office (USDOE, Aibuquerque, New Mexico). Bendix Field Engineering Corporation, Grand Junction Operations, Grand Junction, Cotorado.

Kirkham, R. R., P. A. Beedlow, and G. W. Gee. 1982. "Effect of Rock Cover on Multilayer Radon Barrier Effectiveness." In Proceedings of the Fifth Symposium on Uranium Mill. Tailings Management, pp. 383-395. Colorado State University, Fort Collins, Colorado.

Reynolds, W. D., and D. E. Elrick. 1986. "A Method for Simultaneous In-Situ Measurement in the Vadose Zone of Field Saturated Hydraulic ConductivityPressure Head Relationship." Groundwater Monitoring, Winter Issue, pp. 84-95.

Shuman, R., and F. W. Whicker. 1986. "Intrusion of Reclaimed Uranium Mill Tailings by Prairie Dogs and Ground Squirrels." J. Environ. Qual. $15(1): 21-24$.

U.S. Environmenta] Protection Agency (USEPA). 1983. Final Environmenta] Impact Statement for Standards for the Control of By-product Materials from Uranium Ore Processing (40 CFR 192) Vol. 1. EPA 520/1-83-008-1, Office of Radiation Programs, U.S. Environmental Protection Agency, Washington, D.C. 
APPENDIX A

FIELD SURVEY OF GRAND JUNCTION TEST PLOTS 
APPENDIX A

\section{FIELD SURVEY OF GRAND JUNCTION TEST PLOTS}

A site survey was conducted to identify location of plots that had been established in 1980 and 1981 (Hartley et al. 1980, 1983). A theodolite, stadia rod and a computer with a computer-assisted drawing (CAD) pack were used to map samples locations.

\section{A.1 FIELD SURVEY LAYOUT}

Two primary lines (P1 and P2) were established, from which all angle and distance measurements were made. P1 had its pivot point centered over a water well casing located about $115 \mathrm{ft}$ south of the southeast corner of the 1980 multilayer barrier. The opposite end of P1 was located at the outside edge of the concrete at the southeast corner of the $20-\times 20-\mathrm{ft}$ open well (cistern), about $300 \mathrm{ft}$ east-southeast from the water well. This same point served as the west end of P2. The pivot point of P2 was centered over the neutron access tube in the center of caisson E2.

Angles for P1 were all turned counter-clockwise. Angles for P2 were all turned clockwise and must be subtracted from 180 to use them in conventional layout or calculations. Angle readings were taken in degrees and minutes to the $1 / 10$ th unit. Distance readings were all from stadia in feet, inches, and fractions and were later converted to decimals and reported in metric units (Figure A.1). Stadia readings were assumed to require multiplication by 200 . These assumptions were confirmed only roughly (within 1\%) by tape measurements at the site. Angles between P-lines were measured, and traverse closure for all plots was within 4 in.

Corner points and P-line end points (and two or three other reference points) are shown as multiple concentric circles with a cross in the innermost circle. All measurement sites are represented by a small black dot. At these locations radon flux samples were taken, permeameter tests were run, 


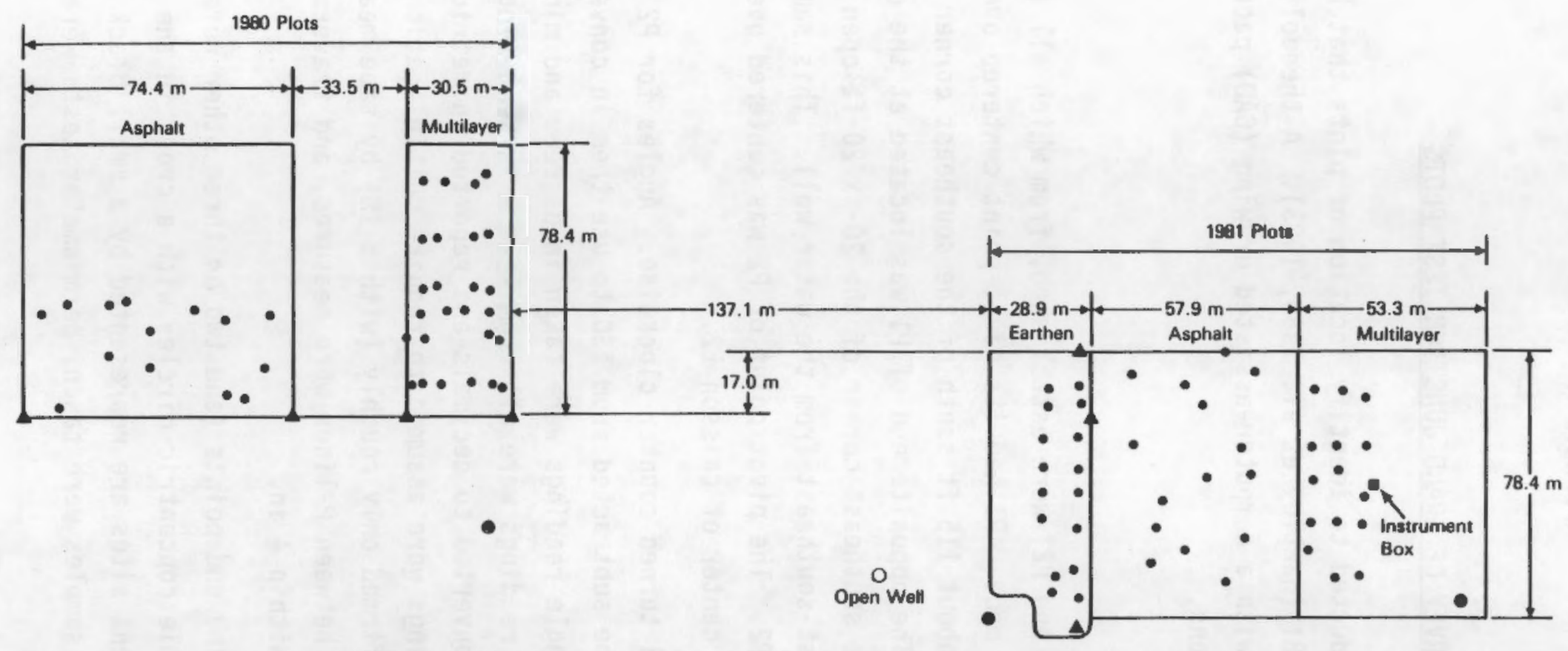

All Distances in Meters

$\triangle$ Plot Boundary Post

- Sample Points

- Reference Post

FIGURE A.1. Survey Map of 1980 and 1981 Test Plots at Grand Junction Tailings Pile 
and a site marker was located. The center of the dot represents the exact location of the soil moisture sampling.

\section{A.2 TEST PLOT FIGURE}

Figure A.l shows the entire survey results with sample points, plot boundary posts and other reference points. Plot dimensions are included for reference. 


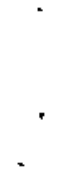




\section{APPENDIX B}

RADON FLUX MEASUREMENTS ON GRAND JUNCTION, COLORADO, TEST COVERS, JUNE 1987 
APPENDIX B

RADON FLUX MEASUREMENTS ON GRAND JUNCTION, COLORADO, TEST COVERS, JUNE 1987 TABLE B.1. Radon Flux Measurements Made June $9-16,1987,20 \mathrm{On}_{1}$ Grand Junction
Tailings Pile. All flux values are in $\mathrm{pC} j \mathrm{~m}^{\mathrm{s}}$

Sample Day Time Day Time Net Radon $\underline{\text { ID(a) }} \underline{\text { on }} \underline{\text { On }} \underline{\text { off }}$ off counts Flux

1980 ASPHALT COVER

$\begin{array}{lrrrrrr}11 \mathrm{~B}-1 & 9 & 8: 04 & 10 & 8: 00 & 666 & 0.9 \\ 11 \mathrm{~B}-2 & 10 & 8: 30 & 11 & 8: 25 & 666 & 0.9 \\ 11 \mathrm{D}-1 & 9 & 7: 56 & 10 & 8: 21 & 766 & 1.1 \\ 11 \mathrm{D}-2 & 10 & 8: 30 & 11 & 8: 25 & 656 & 0.9 \\ 11 \mathrm{D}-3 & 11 & 8: 27 & 12 & 8: 17 & 885 & 1.2 \\ 11 \mathrm{D}-4 & 12 & 8: 25 & 13 & 7: 40 & 740 & 1.1 \\ 11 \mathrm{D}-5 & 13 & 7: 49 & 14 & 7: 29 & 852 & 1.2 \\ 11 \mathrm{D}-6 & 14 & 7: 35 & 15 & 7: 31 & 1283 & 1.8 \\ 11 \mathrm{D}-7 & 15 & 7: 40 & 16 & 7: 29 & 611 & 0.8 \\ 11 \mathrm{D}-8 & 16 & 7: 38 & 17 & 7: 38 & 703 & 0.8 \\ 12 \mathrm{~B}-1 & 9 & 8: 10 & 10 & 8: 14 & 961 & 1.4 \\ 12 \mathrm{~B}-2 & 10 & 8: 22 & 11 & 8: 15 & 958 & 1.4 \\ 12 \mathrm{D}-1 & 9 & 8: 10 & 10 & 8: 21 & 928 & 1.3 \\ 12 \mathrm{D}-2 & 10 & 8: 30 & 11 & 8: 25 & 571 & 0.8 \\ 13 \mathrm{~A}-1 & 9 & 8: 04 & 10 & 8: 30 & 818 & 1.2 \\ 13 \mathrm{~A}-2 & 10 & 8: 39 & 11 & 8: 25 & 1139 & 1.6 \\ 13 \mathrm{~A}-\mathrm{R} & 10 & 8: 39 & 11 & 8: 25 & 792 & 3.3 \\ 13 \mathrm{C}-1 & 9 & 7: 55 & 10 & 8: 21 & 610 & 0.9 \\ 13 \mathrm{C}-\mathrm{R} & 9 & 7: 55 & 10 & 8: 21 & 172 & 0.8 \\ 13 \mathrm{C}-2 & 10 & 8: 30 & 11 & 8: 30 & 922 & 1.3 \\ 14 \mathrm{~B}-1 & 9 & 8: 10 & 10 & 8: 30 & 811 & 1.2 \\ 14 \mathrm{~B}-2 & 10 & 8: 39 & 11 & 8: 25 & 985 & 1.4 \\ 14 \mathrm{C}-1 & 9 & 7: 55 & 10 & \mathrm{~B}: 30 & 331 & 0.5 \\ 14 \mathrm{C}-2 & 10 & 8: 39 & 11 & 8: 25 & 957 & 1.4 \\ 14 \mathrm{C}-3 & 11 & 8: 27 & 12 & 8: 17 & 1448 & 2.0 \\ 14 \mathrm{C}-4 & 12 & 8: 25 & 13 & 7: 40 & 1134 & 1.6 \\ 14 \mathrm{C}-5 & 13 & 7: 49 & 14 & 7: 29 & 1319 & 1.8 \\ 14 \mathrm{C}-6 & 14 & 7: 35 & 15 & 7: 31 & 1365 & 1.9 \\ 14 \mathrm{C}-7 & 15 & 7: 40 & 16 & 7: 29 & 821 & 1.0 \\ 14 \mathrm{C}-8 & 16 & 7: 38 & 17 & 7: 38 & 991 & 1.2 \\ 15 \mathrm{D}-1 & 9 & 7: 55 & 10 & 8: 30 & 764 & 1.1 \\ 15 \mathrm{D}-2 & 10 & 8: 39 & 11 & 8: 15 & 1091 & 1.6 \\ 16 \mathrm{~A}-1 & 9 & 7: 51 & 10 & 8: 14 & 661 & 0.9 \\ & & & & & & \end{array}$

(a) Samples with an $R$ suffix are recounts of original sample 
TABLE B.1. (contd)

$\begin{array}{crrrrrr}\begin{array}{c}\text { Sample } \\ \text { ID }\end{array} & \begin{array}{c}\text { Day } \\ \text { On }\end{array} & \begin{array}{c}\text { Time } \\ \text { On }\end{array} & \begin{array}{c}\text { Day } \\ \text { Off }\end{array} & \begin{array}{c}\text { Time } \\ \text { Off }\end{array} & \begin{array}{r}\text { Net } \\ \text { Counts }\end{array} & \begin{array}{r}\text { Radon } \\ \text { Elux }\end{array} \\ 16 A-2 & 10 & 8: 22 & 11 & 8: 15 & 721 & 1.0 \\ 17 B-1 & 9 & 7: 51 & 10 & 8: 14 & 101070 & 141.9 \\ 17 B-2 & 10 & 8: 22 & 11 & 8: 15 & 62535 & 87.9 \\ 18 D-1 & 9 & 7: 51 & 10 & 8: 14 & 666 & 0.9 \\ 18 D-2 & 10 & 8: 22 & 11 & 8: 15 & 1175 & 1.7 \\ 18 D-3 & 11 & 8: 27 & 12 & 8: 17 & 991 & 1.4 \\ 18 D-4 & 12 & 8: 25 & 13 & 7: 40 & 854 & 1.2 \\ 18 D-5 & 13 & 7: 49 & 14 & 7: 29 & 1068 & 1.5 \\ 18 D-6 & 14 & 7: 35 & 15 & 7: 31 & 1164 & 1.6 \\ 18 D-7 & 15 & 7: 40 & 16 & 7: 29 & 327 & 0.4 \\ 18 D-8 & 16 & 7: 38 & 17 & 7: 38 & 855 & 1.0 \\ 19 B-1 & 9 & 7: 51 & 10 & 8: 40 & 700 & 1.0 \\ 19 B-2 & 10 & 8: 47 & 11 & 8: 15 & 761 & 1.1 \\ 20 A-1 & 9 & 8: 10 & 10 & 8: 40 & 449 & 0.6 \\ 20 A-2 & 10 & 8: 47 & 11 & 8: 15 & 0 & 0.0 \\ 20 A-R & 10 & 8: 47 & 11 & 8: 15 & 920 & 3.9 \\ 20 C-1 & 9 & 7: 55 & 10 & 8: 40 & 587 & 0.8 \\ 20 C-2 & 10 & 8: 47 & 11 & 8: 15 & 807 & 1.2 \\ 20 C-3 & 11 & 8: 27 & 12 & 8: 17 & 1438 & 2.0 \\ 20 C-4 & 12 & 8: 25 & 13 & 7: 40 & 1146 & 1.6 \\ 20 C-5 & 13 & 7: 49 & 14 & 7: 29 & 1610 & 2.3 \\ 20 C-6 & 14 & 7: 35 & 15 & 7: 31 & 1249 & 1.7 \\ 20 C-7 & 15 & 7: 40 & 16 & 7: 29 & 965 & 1.2 \\ 20 C-8 & 16 & 7: 38 & 17 & 7: 38 & 1365 & 1.7\end{array}$

1980 MULTILAYER BARRIERS.

$\begin{array}{lrrrrrr}01-1 & 9 & 7: 43 & 10 & 7: 59 & 31578 & 44.4 \\ 01-2 & 10 & 8: 08 & 11 & 7: 35 & 18166 & 26.0 \\ 02-1 & 9 & 7: 43 & 10 & 7: 59 & 9652 & 13.6 \\ 02-\mathrm{R} & 9 & 7: 43 & 10 & 7: 59 & 2633 & 12.8 \\ 02-2 & 10 & 8: 08 & 11 & 7: 35 & 12980 & 18.6 \\ 03-1 & 9 & 7: 43 & 10 & 7: 59 & 40585 & 57.2 \\ 03-2 & 10 & 8: 08 & 11 & 7: 35 & 50823 & 72.9 \\ 04-1 & 9 & 7: 43 & 10 & 7: 59 & 82805 & 117.2 \\ 04-\mathrm{R} & 9 & 7: 43 & 10 & 7: 59 & 72727 & 149.9 \\ 04-\mathrm{R} 2 & 9 & 7: 43 & 10 & 7: 59 & 62468 & 128.3 \\ 04-2 & 10 & 8: 08 & 11 & 7: 35 & 61521 & 88.5 \\ 05-1 & 9 & 7: 39 & 10 & 7: 49 & 2248 & 3.2 \\ 05-2 & 10 & 7: 58 & 11 & 7: 35 & 2847 & 4.0 \\ 05-3 & 11 & 7: 52 & 12 & 7: 58 & 1767 & 2.1 \\ 05-4 & 12 & 8: 12 & 13 & 7: 22 & 1303 & 1.6 \\ 06-1 & 9 & 7: 39 & 10 & 7: 49 & 1709 & 2.4 \\ 06-2 & 10 & 7: 58 & 11 & 7: 35 & 2703 & 3.8 \\ 06-3 & 11 & 7: 52 & 12 & 7: 58 & 740 & 0.9\end{array}$


TABLE B.1. (contd)

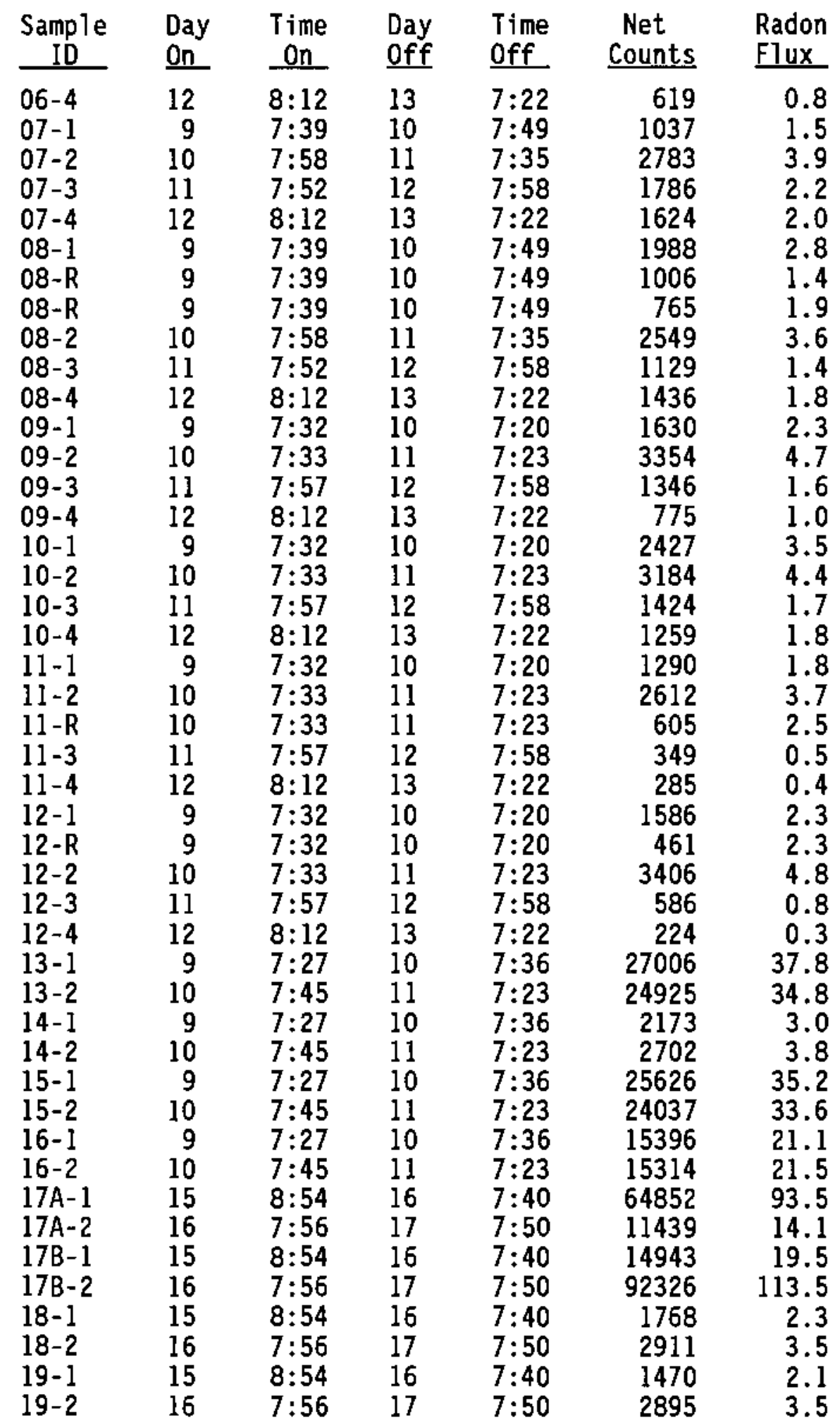


IABLE B.1. (contd)

\begin{tabular}{|c|c|c|c|c|c|c|}
\hline $\begin{array}{c}\text { Sample } \\
\text { ID } \\
\end{array}$ & $\begin{array}{l}\text { Day } \\
\text { On }\end{array}$ & $\begin{array}{l}\text { Time } \\
\text { On } \\
\end{array}$ & $\begin{array}{l}\text { Day } \\
\text { Off }\end{array}$ & $\begin{array}{l}\text { Time } \\
\text { Off } \\
\end{array}$ & $\begin{array}{l}\text { Net } \\
\text { Counts }\end{array}$ & $\begin{array}{l}\text { Radon } \\
\text { Flux } \\
\end{array}$ \\
\hline $\begin{array}{l}20 A-1 \\
20 A-2 \\
20 B-1 \\
20 B-2 \\
21 A-1 \\
21 A-2 \\
21 B-1 \\
21 B-2 \\
22 A-1 \\
22 A-2 \\
22 B-1 \\
22 B-2\end{array}$ & $\begin{array}{l}15 \\
16 \\
15 \\
16 \\
15 \\
16 \\
15 \\
16 \\
15 \\
16 \\
15 \\
16\end{array}$ & $\begin{array}{l}8: 54 \\
7: 56 \\
8: 54 \\
7: 56 \\
8: 54 \\
7: 56 \\
8: 54 \\
7: 56 \\
8: 55 \\
7: 56 \\
8: 54 \\
7: 56\end{array}$ & $\begin{array}{l}16 \\
17 \\
16 \\
17 \\
16 \\
17 \\
16 \\
17 \\
16 \\
17 \\
16 \\
17\end{array}$ & $\begin{array}{l}7: 40 \\
7: 50 \\
7: 40 \\
7: 50 \\
7: 40 \\
7: 50 \\
7: 40 \\
7: 50 \\
7: 40 \\
7: 50 \\
7: 40 \\
7: 50\end{array}$ & $\begin{array}{r}1866 \\
3646 \\
85635 \\
71974 \\
5610 \\
5474 \\
93840 \\
193104 \\
21804 \\
50959 \\
1967 \\
1665\end{array}$ & $\begin{array}{r}2.7 \\
4.4 \\
122.7 \\
98.3 \\
8.1 \\
6.7 \\
134.7 \\
235.5 \\
31.5 \\
58.0 \\
2.8 \\
2.3\end{array}$ \\
\hline
\end{tabular}

1981 MULTILAYER

$\begin{array}{rrrrrrr}42-1 & 13 & 8: 49 & 14 & 8: 07 & 80 \mathrm{~B} 31 & 114.6 \\ 42-2 & 14 & 8: 21 & 15 & 8: 22 & 40594 & 55.9 \\ 44-1 & 13 & 8: 49 & 14 & 8: 07 & 23841 & 33.9 \\ 44-2 & 14 & 8: 21 & 15 & 8: 22 & 36991 & 51.0 \\ 46-1 & 13 & 8: 49 & 14 & 8: 07 & 23946 & 34.1 \\ 46-2 & 14 & 8: 21 & 15 & 8: 22 & 32557 & 45.0 \\ 47-1 & 13 & 8: 49 & 14 & 8: 07 & 22114 & 31.5 \\ 47-R & 13 & 8: 49 & 14 & 8: 07 & 11415 & 29.0 \\ 47-2 & 14 & 8: 21 & 15 & 8: 22 & 25588 & 35.4 \\ 49-1 & 13 & 8: 49 & 14 & 8: 07 & 11967 & 17.1 \\ 49-2 & 14 & 8: 21 & 15 & 8: 22 & 4885 & 6.8 \\ 52-1 & 13 & 8: 49 & 14 & 8: 07 & 95331 & 136.3 \\ 52-2 & 14 & 8: 21 & 15 & 8: 22 & 91514 & 127.0 \\ 54-1 & 13 & 8: 49 & 14 & 8: 07 & 63171 & 90.5 \\ 54-2 & 14 & 8: 21 & 15 & 8: 22 & 42078 & 58.5 \\ 55-1 & 13 & 8: 49 & 14 & 8: 08 & 68812 & 98.6 \\ 55-2 & 14 & 8: 21 & 15 & 8: 22 & 82077 & 114.3 \\ 57-1 & 13 & 8: 49 & 14 & 8: 07 & 41718 & 59.9 \\ 57-2 & 14 & 8: 21 & 15 & 8: 22 & 42790 & 59.7 \\ 59-1 & 13 & 8: 49 & 14 & 8: 07 & 61453 & 88.4 \\ 59-R & 13 & 8: 49 & 14 & 8: 07 & 23533 & 60.2 \\ 59-2 & 14 & 8: 21 & 15 & 8: 22 & 15124 & 21.1 \\ 62-1 & 13 & 8: 51 & 14 & 8: 07 & 167633 & 241.7 \\ 62-2 & 14 & 8: 21 & 15 & 8: 22 & 156000 & 218.1 \\ 64-1 & 13 & 8: 51 & 14 & 8: 07 & 45671 & 66.0 \\ 64-2 & 14 & 8: 21 & 15 & 8: 22 & 77802 & 108.9 \\ 67-1 & 13 & 8: 51 & 14 & 8: 07 & 24282 & 35.1 \\ 67-2 & 14 & 8: 21 & 15 & 8: 22 & 34239 & 48.0 \\ 68-1 & 13 & 8: 51 & 14 & 8: 07 & 31798 & 46.0\end{array}$


TABLE B.1. (contd)

\begin{tabular}{|c|c|c|c|c|c|c|}
\hline $\begin{array}{c}\text { Sample } \\
\text { ID } \\
\end{array}$ & $\begin{array}{l}\text { Day } \\
\text { On }\end{array}$ & $\begin{array}{l}\text { Time } \\
\text { On } \\
\end{array}$ & $\begin{array}{l}\text { Day } \\
\text { Off }\end{array}$ & $\begin{array}{l}\text { Time } \\
\text { Off }\end{array}$ & $\begin{array}{l}\text { Net } \\
\text { Counts } \\
\end{array}$ & $\begin{array}{l}\text { Radon } \\
\text { Flux }\end{array}$ \\
\hline $\begin{array}{l}68-2 \\
69-1 \\
69-2\end{array}$ & $\begin{array}{l}14 \\
13 \\
14\end{array}$ & $\begin{array}{l}8: 21 \\
8: 51 \\
8: 21\end{array}$ & $\begin{array}{l}15 \\
14 \\
15\end{array}$ & $\begin{array}{l}8: 22 \\
8: 07 \\
8: 22\end{array}$ & $\begin{array}{l}45165 \\
54890 \\
39051\end{array}$ & $\begin{array}{l}63.4 \\
79.6 \\
54.9\end{array}$ \\
\hline
\end{tabular}

1981 ASPHALT COVERS

$\begin{array}{lrrrrrr}081-1 & 9 & 8: 25 & 10 & 8: 55 & 891 & 1.3 \\ 081-2 & 10 & 9: 04 & 11 & 9: 09 & 811 & 1.2 \\ 081-3 & 11 & 9: 21 & 12 & 8: 45 & 913 & 1.3 \\ 081-4 & 12 & 9: 05 & 13 & 8: 19 & 816 & 1.2 \\ 081-\mathrm{R} & 12 & 9: 05 & 13 & 8: 19 & 725 & 2.2 \\ 081-5 & 13 & 8: 24 & 14 & 7: 57 & 1350 & 1.7 \\ 081-6 & 14 & 8: 02 & 15 & 8: 04 & 1283 & 1.5 \\ 081-7 & 15 & 8: 12 & 16 & 8: 31 & 408 & 0.5 \\ 081-8 & 16 & 8: 41 & 17 & 8: 22 & 1341 & 1.6 \\ 085-1 & 11 & 9: 21 & 12 & 8: 45 & 1385 & 2.0 \\ 085-2 & 12 & 9: 05 & 13 & 8: 19 & 1022 & 1.5 \\ 087-1 & 11 & 9: 21 & 12 & 8: 45 & 769 & 1.1 \\ 087-2 & 12 & 9: 05 & 13 & 8: 19 & 866 & 1.2 \\ 091-1 & 11 & 9: 26 & 12 & 8: 45 & 1259 & 1.8 \\ 091-2 & 12 & 9: 05 & 13 & 8: 19 & 1123 & 1.6 \\ 094-1 & 11 & 9: 21 & 12 & 8: 45 & 736 & 1.1 \\ 094-2 & 12 & 9: 05 & 13 & 8: 19 & 680 & 1.0 \\ 099-1 & 9 & 8: 25 & 10 & 8: 55 & 586 & 0.8 \\ 099-2 & 10 & 9: 04 & 11 & 9: 09 & 670 & 1.0 \\ 099-3 & 11 & 9: 26 & 12 & 8: 45 & 1227 & 1.8 \\ 099-\mathrm{R} & 11 & 9: 26 & 12 & 8: 45 & 495 & 1.8 \\ 099-4 & 12 & 9: 05 & 13 & 8: 19 & 916 & 1.3 \\ 099-5 & 13 & 8: 24 & 14 & 7: 57 & 1674 & 2.1 \\ 099-6 & 14 & 8: 02 & 15 & 8: 04 & 1307 & 1.6 \\ 099-7 & 15 & 8: 12 & 16 & 8: 31 & 398 & 0.5 \\ 099-8 & 16 & 8: 41 & 17 & 8: 22 & 329 & 0.4 \\ 103-1 & 11 & 9: 29 & 12 & 8: 45 & 934 & 1.4 \\ 103-2 & 12 & 9: 07 & 13 & 8: 19 & 976 & 1.4 \\ 105-1 & 11 & 9: 29 & 12 & 8: 45 & 1541 & 2.2 \\ 105-R & 11 & 9: 29 & 12 & 8: 45 & 427 & 1.5 \\ 105-2 & 12 & 9: 07 & 13 & 8: 19 & 1487 & 2.2 \\ 108-1 & 11 & 9: 29 & 12 & 8: 45 & 1004 & 1.5 \\ 108-2 & 12 & 9: 07 & 13 & 8: 19 & 800 & 1.2 \\ 112-1 & 11 & 9: 32 & 12 & 8: 58 & 9931 & 14.4 \\ 112-2 & 12 & 9: 07 & 13 & 8: 19 & 7391 & 10.8 \\ 116-1 & 9 & 8: 25 & 10 & 8: 55 & 969 & 1.4 \\ 116-2 & 10 & 9: 04 & 11 & 9: 09 & 689 & 1.0 \\ 116-3 & 11 & 9: 32 & 12 & 8: 58 & 1184 & 1.7 \\ 116-4 & 12 & 9: 07 & 13 & 8: 19 & 802 & 1.2\end{array}$


TABLE B.1. (contd)

$\begin{array}{cccccrr}\begin{array}{c}\text { Sample } \\ \text { ID }\end{array} & \begin{array}{c}\text { Day } \\ \text { On }\end{array} & \begin{array}{c}\text { Time } \\ \text { On }\end{array} & \begin{array}{c}\text { Day } \\ \text { Off }\end{array} & \begin{array}{c}\text { Time } \\ \text { Off }\end{array} & \begin{array}{r}\text { Net } \\ \text { Counts }\end{array} & \begin{array}{r}\text { Radon } \\ \text { Flux }\end{array} \\ 116-5 & 13 & 8: 24 & 14 & 7: 57 & 2100 & 2.6 \\ 116-6 & 14 & 8: 02 & 15 & 8: 04 & 2073 & 2.5 \\ 116-7 & 15 & 8: 12 & 16 & 8: 31 & 944 & 1.1 \\ 116-8 & 16 & 8: 41 & 17 & 8: 22 & 1100 & 1.3 \\ 121-1 & 11 & 9: 32 & 12 & 8: 58 & 870 & 1.3 \\ 121-2 & 12 & 9: 07 & 13 & 8: 19 & 1018 & 1.5 \\ 124-1 & 11 & 9: 35 & 12 & 8: 58 & 4351 & 6.3 \\ 124-2 & 12 & 9: 09 & 13 & 8: 19 & 2530 & 3.7 \\ 127-1 & 9 & 8: 25 & 10 & 8: 55 & 40166 & 57.2 \\ 127-R & 9 & 8: 25 & 10 & 8: 55 & 32002 & 54.2 \\ 127-R & 9 & 8: 25 & 10 & 8: 55 & 28330 & 57.2 \\ 127-2 & 10 & 9: 04 & 11 & 9: 09 & 33067 & 47.0 \\ 127-3 & 11 & 9: 35 & 12 & 8: 58 & 23775 & 34.7 \\ 127-4 & 12 & 9: 09 & 13 & 8: 19 & 14565 & 21.3 \\ 127-5 & 13 & 8: 24 & 14 & 7: 57 & 38164 & 47.1 \\ 127-6 & 14 & 8: 02 & 15 & 8: 04 & 29370 & 35.5 \\ 127-7 & 15 & 8: 12 & 16 & 8: 31 & 22967 & 27.4 \\ 127-8 & 16 & 8: 41 & 17 & 8: 22 & 6117 & 7.3 \\ 129-1 & 11 & 9: 35 & 12 & 8: 58 & 788 & 1.2 \\ 129-2 & 12 & 9: 09 & 13 & 8: 19 & 1350 & 2.0\end{array}$

\section{EARTHEN COVERS}

$\begin{array}{lllllrr}142-1 & 11 & 8: 04 & 12 & 8: 29 & 1975 & 2.7 \\ 142-2 & 12 & 8: 39 & 13 & 7: 58 & 1242 & 1.8 \\ 142-\mathrm{R} & 12 & 8: 39 & 13 & 7: 58 & 227 & 0.7 \\ 142-3 & 13 & 8: 10 & 14 & 7: 39 & 1836 & 2.3 \\ 142-4 & 14 & 7: 52 & 15 & 7: 45 & 1639 & 2.0 \\ 142-5 & 16 & 8: 16 & 17 & 8: 04 & 1543 & 1.9 \\ 142-6 & 15 & 8: 12 & 16 & 8: 31 & 461 & 0.6 \\ 143-1 & 11 & 8: 04 & 12 & 8: 29 & 8549 & 11.6 \\ 143-2 & 12 & 8: 39 & 13 & 7: 58 & 5961 & 8.5 \\ 143-3 & 13 & 8: 10 & 14 & 7: 39 & 4709 & 6.6 \\ 143-4 & 14 & 7: 52 & 15 & 7: 45 & 5195 & 7.1 \\ 143-5 & 16 & 8: 16 & 17 & 8: 04 & 6433 & 7.8 \\ 143-6 & 15 & 8: 00 & 16 & 8: 04 & 6346 & 7.7 \\ 145-1 & 13 & 8: 12 & 14 & 7: 39 & 43008 & 52.6 \\ 145-2 & 14 & 7: 52 & 15 & 7: 45 & 38481 & 46.3 \\ 147-1 & 13 & 8: 12 & 14 & 7: 39 & 16526 & 20.3 \\ 147-2 & 14 & 7: 52 & 15 & 7: 45 & 23670 & 28.6 \\ 149-1 & 11 & 8: 04 & 12 & 8: 29 & 75705 & 102.2 \\ 149-\mathrm{R} & 11 & 8: 04 & 12 & 8: 29 & 30953 & 104.6 \\ 149-2 & 12 & 8: 39 & 13 & 7: 58 & 19677 & 27.8 \\ 149-3 & 13 & 8: 10 & 14 & 7: 39 & 57456 & 85.6 \\ 149-4 & 14 & 7: 52 & 15 & 7: 45 & 43305 & 52.9\end{array}$


TABLE_B.1. (contd)

\begin{tabular}{cccccrr}
$\begin{array}{ccccc}\text { Sample } \\
\text { ID }\end{array}$ & $\begin{array}{l}\text { Day } \\
\text { On }\end{array}$ & $\begin{array}{c}\text { Time } \\
\text { On }\end{array}$ & $\begin{array}{c}\text { Day } \\
\text { Off }\end{array}$ & $\begin{array}{c}\text { Time } \\
\text { Off }\end{array}$ & $\begin{array}{c}\text { Net } \\
\text { Counts }\end{array}$ & $\begin{array}{r}\text { Radon } \\
\text { Flux }\end{array}$ \\
\cline { 1 - 2 } $149-5$ & 16 & $8: 16$ & 17 & $8: 04$ & 45919 & 55.0 \\
$149-6$ & 15 & $8: 12$ & 16 & $8: 31$ & 43608 & 52.1 \\
$150-1$ & 11 & $8: 04$ & 12 & $8: 29$ & 109138 & 147.0 \\
$150-2$ & 12 & $8: 39$ & 13 & $7: 58$ & 39755 & 56.0 \\
$150-3$ & 13 & $8: 10$ & 14 & $7: 39$ & 66856 & 82.9 \\
$150-4$ & 14 & $7: 52$ & 15 & $7: 45$ & 42127 & 51.4 \\
$150-5$ & 15 & $8: 00$ & 16 & $8: 04$ & 60905 & 73.6 \\
$150-6$ & 16 & $8: 16$ & 17 & $8: 04$ & 62783 & 75.1 \\
$159-1$ & 11 & $8: 04$ & 12 & $8: 29$ & 56985 & 77.2 \\
$159-2$ & 12 & $8: 39$ & 13 & $7: 58$ & 42805 & 60.6 \\
$159-R$ & 12 & $8: 39$ & 13 & $7: 58$ & 19226 & 58.3 \\
$159-3$ & 13 & $8: 10$ & 14 & $7: 39$ & 32993 & 41.1 \\
$159-4$ & 14 & $7: 52$ & 15 & $7: 45$ & 20736 & 25.4 \\
$159-R$ & 14 & $8: 10$ & 15 & $7: 39$ & 14654 & 31.2 \\
$159-5$ & 15 & $8: 00$ & 16 & $8: 04$ & 10681 & 13.0 \\
$159-6$ & 16 & $8: 16$ & 17 & $8: 04$ & 30224 & 36.3 \\
$160-1$ & 11 & $8: 04$ & 12 & $8: 29$ & 87022 & 117.6 \\
$160-2$ & 12 & $8: 39$ & 13 & $7: 58$ & 62130 & 87.8 \\
$160-3$ & 13 & $8: 10$ & 14 & $7: 39$ & 72344 & 90.0 \\
$160-4$ & 14 & $7: 52$ & 15 & $7: 45$ & 56422 & 69.1 \\
$160-5$ & 15 & $8: 00$ & 16 & $8: 04$ & 65166 & 79.0 \\
$160-6$ & 16 & $8: 16$ & 17 & $8: 04$ & 65103 & 78.1 \\
$162-1$ & 11 & $8: 04$ & 12 & $8: 29$ & 2066 & 2.8 \\
$162-2$ & 12 & $8: 39$ & 13 & $7: 58$ & 1352 & 1.9 \\
$162-3$ & 13 & $8: 10$ & 14 & $7: 39$ & 1459 & 2.0 \\
$162-4$ & 14 & $7: 52$ & 15 & $7: 45$ & 944 & 1.3 \\
$162-5$ & 15 & $8: 00$ & 16 & $8: 04$ & 819 & 1.0 \\
$162-6$ & 16 & $8: 16$ & 17 & $8: 04$ & 1632 & 2.0 \\
$163-1$ & 11 & $8: 04$ & 12 & $8: 29$ & 4044 & 5.6 \\
$163-2$ & 12 & $8: 39$ & 13 & $7: 58$ & 3097 & 4.4 \\
$163-3$ & 13 & $8: 10$ & 14 & $7: 39$ & 3123 & 4.4 \\
$163-4$ & 14 & $7: 52$ & 15 & $7: 45$ & 2607 & 3.6 \\
$163-5$ & 15 & $8: 00$ & 16 & $8: 04$ & 2760 & 3.4 \\
$163-6$ & 16 & $8: 16$ & 17 & $8: 04$ & 3880 & 4.7 \\
$165-1$ & 13 & $8: 12$ & 14 & $7: 39$ & 38674 & 47.4 \\
$165-2$ & 14 & $7: 52$ & 15 & $7: 45$ & 37475 & 45.0 \\
$167-1$ & 13 & $8: 12$ & 14 & $8: 12$ & 16526 & 19.8 \\
$167-2$ & 14 & $7: 52$ & 15 & $7: 45$ & 10481 & 12.7
\end{tabular}

\section{COLUMN TESTS}

$\begin{array}{rrrrrrr}\text { A-1-1 } & 15 & 8: 45 & 16 & 8: 04 & 14111 & 17.9 \\ \text { A-1-2 } & 16 & 8: 30 & 17 & 8: 11 & 1602 & 2.0 \\ \text { E-1-1 } & 15 & 8: 45 & 16 & 8: 04 & 25191 & 30.9\end{array}$


TABLE B.1. (contd)

\begin{tabular}{|c|c|c|c|c|c|c|}
\hline $\begin{array}{c}\text { Sample } \\
\text { ID }\end{array}$ & $\begin{array}{l}\text { Day } \\
\text { On } \\
\end{array}$ & $\begin{array}{l}\text { Time } \\
\text { On } \\
\end{array}$ & $\begin{array}{l}\text { Day } \\
\text { Off }\end{array}$ & $\begin{array}{l}\text { Time } \\
\text { Off }\end{array}$ & $\begin{array}{l}\text { Net } \\
\text { Counts }\end{array}$ & $\begin{array}{l}\text { Radon } \\
\text { Flux }\end{array}$ \\
\hline $\begin{array}{l}E-1-2 \\
E-2-1 \\
E-2-2 \\
E-3-1 \\
E-3-2 \\
E-4-1 \\
E-4-2 \\
M-1-1 \\
M-1-2 \\
M-2-1 \\
M-2-2\end{array}$ & $\begin{array}{l}16 \\
15 \\
16 \\
15 \\
16 \\
15 \\
16 \\
15 \\
16 \\
15 \\
16\end{array}$ & $\begin{array}{l}8: 30 \\
8: 45 \\
8: 30 \\
8: 45 \\
8: 30 \\
8: 45 \\
8: 30 \\
8: 45 \\
8: 30 \\
8: 45 \\
8: 30\end{array}$ & $\begin{array}{l}17 \\
16 \\
17 \\
16 \\
17 \\
16 \\
17 \\
16 \\
17 \\
16 \\
17\end{array}$ & $\begin{array}{l}8: 11 \\
8: 04 \\
8: 11 \\
8: 04 \\
8: 11 \\
8: 04 \\
8: 11 \\
8: 04 \\
8: 11 \\
8: 04 \\
8: 11\end{array}$ & $\begin{array}{r}20582 \\
56945 \\
43825 \\
45585 \\
37633 \\
121185 \\
197794 \\
1856 \\
13092 \\
14715 \\
12983\end{array}$ & $\begin{array}{r}24.1 \\
70.0 \\
52.4 \\
56.1 \\
44.7 \\
149.1 \\
235.3 \\
2.4 \\
16.2 \\
18.7 \\
16.0\end{array}$ \\
\hline
\end{tabular}

BARE TAILINGS

$\begin{array}{lllllll}\text { T-1-1 } & 15 & 8: 54 & 16 & 7: 40 & 506453 & 733.6 \\ \text { T-1-2 } & 16 & 7: 56 & 17 & 7: 50 & 398150 & 545.5 \\ \text { GH-1-1 } & 15 & 8: 56 & 16 & 7: 40 & 280207 & 407.2 \\ \text { GH-1-2 } & 16 & 7: 56 & 17 & 7: 50 & 269520 & 368.7\end{array}$




\section{APPENDIX C}

CLIMATE SUMMARY 
APPENDIX C

\section{CLIMATE SUMMARY}

IABLE C.1. Precipitation (in inches) for Grand Junction, Colorado (January 1980 through May 1987)

\begin{tabular}{|c|c|c|c|c|c|c|c|c|c|c|c|c|c|}
\hline Year & $\underline{\text { Jan }}$ & Eeb & Mar & Apr & May & Jun & $\mathrm{Jul}$ & Aug & $\underline{\text { Sep }}$ & $\underline{\text { Oct }}$ & Nov & Dec & IOTAL \\
\hline 1980 & 0.57 & 1.10 & 1.77 & 0.53 & 1.17 & $\mathrm{Tr}$ & 0.96 & 1.39 & 0.58 & 1.31 & 0.52 & 0.24 & 10.14 \\
\hline 1981 & 0.44 & 0.16 & 1.35 & 0.56 & 1.49 & 0.17 & 0.41 & 0.82 & 0.25 & 2.06 & 0.47 & 0.60 & 8.78 \\
\hline 1982 & 0.29 & 0.41 & 0.79 & 0.09 & 0.75 & 0.21 & 0.35 & 0.94 & 2.81 & 0.83 & 0.48 & 0.27 & 8.22 \\
\hline 1983 & 0.50 & 0.64 & 1.59 & 0.90 & 1.68 & 1.54 & 1.92 & 0.73 & 1.11 & 0.36 & 2.00 & 1.85 & 14.82 \\
\hline 1984 & 0.28 & 0.11 & 1.57 & 1.21 & 0.55 & 1.68 & 0.62 & 1.77 & 0.34 & 2.65 & 0.38 & 0.43 & 11.59 \\
\hline 1985 & 0.51 & 0.26 & 0.92 & 1.78 & 1.09 & 0.39 & 1.21 & 0.24 & 1.67 & 2.32 & 1.10 & 0.73 & 12.22 \\
\hline 1986 & 0.13 & 0.33 & 0.25 & 0.71 & 1.15 & 0.15 & 0.94 & 0.97 & 1.52 & 1.22 & 1.02 & 0.47 & 7.61 \\
\hline 1987 & 0.30 & $\underline{1.21}$ & $\underline{1.95}$ & $\underline{0.46}$ & 1.51 & - & -- & - & -- & - & $=$ & $=$ & -. \\
\hline
\end{tabular}


. 


\section{APPENDIX D}

CHARACTERISTICS OF SOIL COVER MATERIALS

AT GRAND JUNCTION, COLORADO 


\section{APPENDIX D}

\section{CHARACTERISTICS OF SOIL COVER MATERIALS \\ AT GRAND JUNCTION, COLORADO}

TABLE D.1. Grand Junction Radon Barrier Soils - Physical Characteristics

\begin{tabular}{|c|c|c|c|c|c|c|c|c|c|c|}
\hline & \multicolumn{3}{|c|}{ Texture_utx) } & \multicolumn{3}{|c|}{ Density $\left(\mathrm{g} \mathrm{cm}^{-3}\right)$. } & \multicolumn{4}{|c|}{ Tension $^{(a)}($ vol $x)$} \\
\hline & $\underline{\underline{S}}$ & $\underline{\mathbf{s i}}$ & $\underline{c^{(b)}}$ & Clod & Particle & Senple & 0 & 500 & 1000 & 5000 \\
\hline 1980 Asphalt t & 18 & 42 & 40 & 1.40 & $2 . \pi$ & 1.20 & 38.3 & 17.8 & 16.7 & 13.4 \\
\hline 1980 Multiloyer & 13 & 45 & 42 & 1.38 & 2.81 & 1.29 & 39.7 & 23.6 & 22.4 & 15.8 \\
\hline 1981 Earthen Cover & 25 & 40 & 35 & 1.58 & 2.70 & 1.28 & 32.3 & 19.6 & 18.5 & 13.1 \\
\hline 1981 Asphalt & 21 & 43 & 36 & 1.43 & 2.74 & 1.29 & 37.3 & 18.5 & 17.3 & 12.9 \\
\hline 1981 multilayer & 19 & 42 & 39 & 1.47 & 2.74 & 1.28 & 36.1 & 19.8 & 18.6 & 13.8 \\
\hline 1981 Caissons & 25 & 41 & 34 & N.D. ${ }^{(c)}$ & 2.71 & 1.26 & 36.7 & 18.1 & 17.4 & 12.6 \\
\hline $\operatorname{mix}$ & $\boldsymbol{2}$ & 39 & 38 & M.D. & 2.78 & 1.27 & 36.7 & 20.9 & 20.1 & 14.5 \\
\hline Averago & 20 & 42 & 30 & 1.45 & $2 . \pi 5$ & 1.28 & 36.7 & 19.7 & 18.7 & †3.7 \\
\hline
\end{tabular}

(a) Measured in $\mathrm{COH} \mathrm{H}_{2} \mathrm{O}$.

(b) $\mathrm{Se}=\mathrm{Sand} ; \mathrm{Si}=\mathrm{Silt} ; \mathrm{Cl}=\mathrm{Clay}$.

(c) N.D. = Not determined. 
IABLE D.2. Grand Junction Mill Tailings Pile Barriers Permeameter Test Results(a)

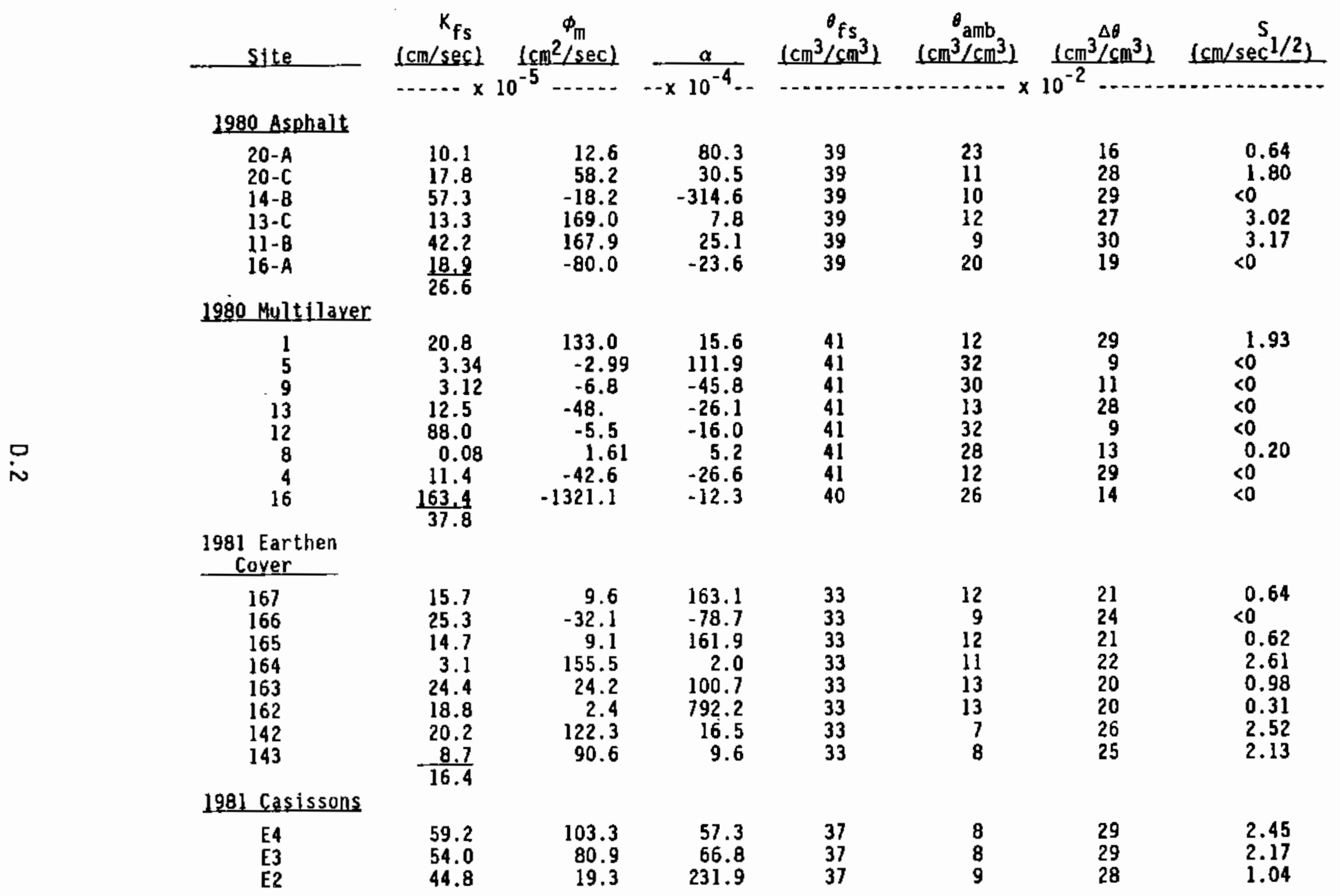


TABLE D.2. (contd)

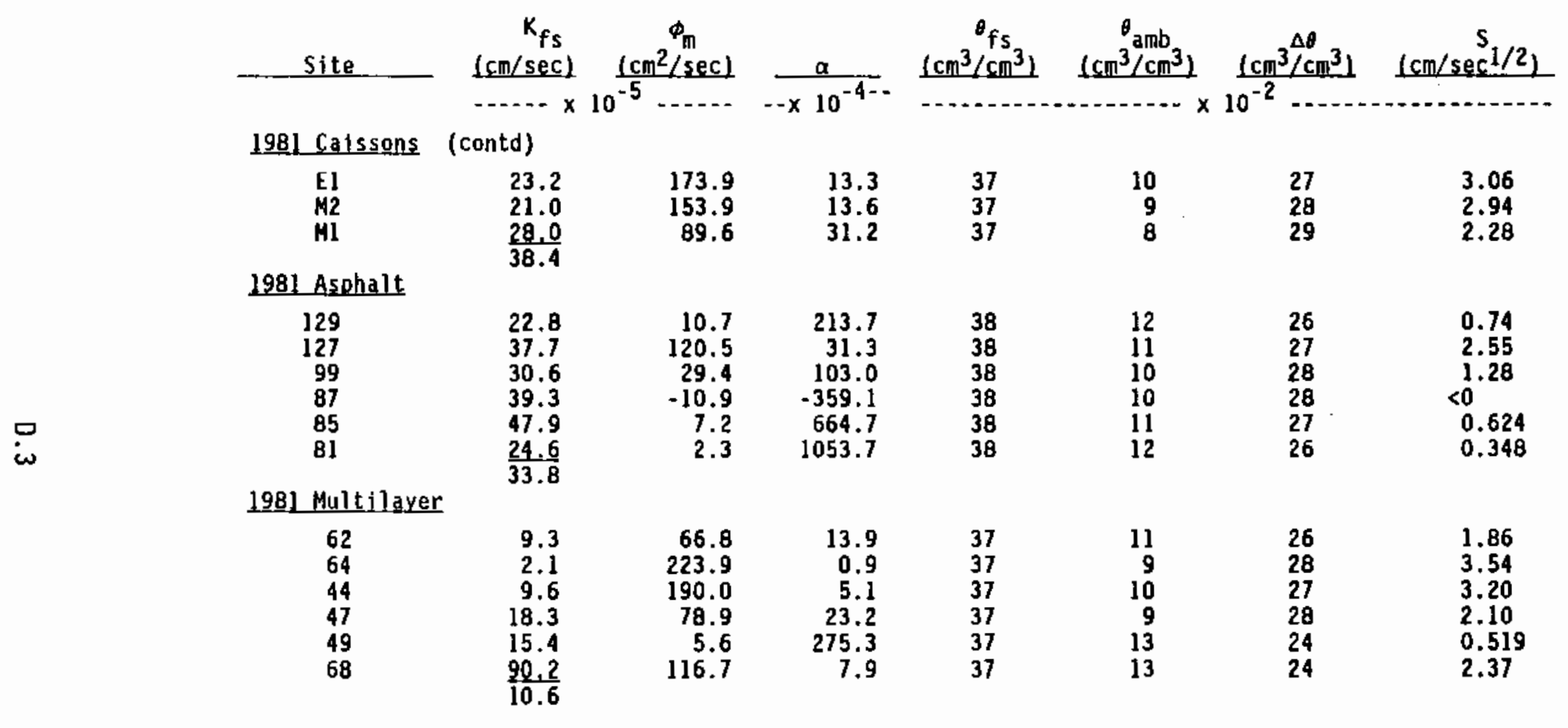

(a) Definition of symbols used in Geulph Permeameter Tests (see Reynolds and Elrich, 1986)

$K_{f s}=$ field saturated hydraulic conductivity

$\Phi_{\mathrm{m}}=$ matric flux potential

$\alpha=$ slope of the water plot of $\ln K(\theta)$ vs matric potential

$\theta_{f s}=$ field saturated water content

$\theta_{\text {amb }}=$ initial field water content (before saturation)

$\Delta \theta=\theta_{\mathrm{fs}}-\theta_{\mathrm{amb}}$

$S=$ Sorptivity $=\left(2(\Delta \theta) \phi_{\mathrm{m}}\right)^{1 / 2}$ 
IABLE D.3. Measurement Parameters Used to Compute Field Hydraulic Conductivity on Grand Junction Test Plots

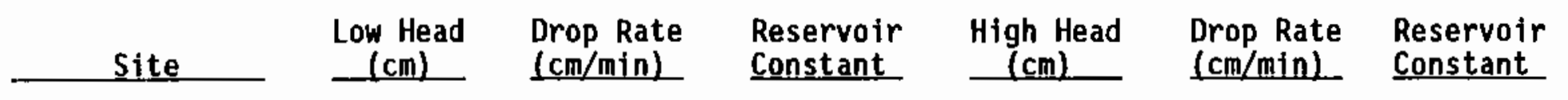

1980 Asphalt

$\begin{array}{lll}20-A & 5.0 & 0.80 \\ 20-C & 5.0 & 1.70 \\ 14-B & 5.0 & 3.30 \\ 13-C & 5.0 & 2.60 \\ 11-B & 5.0 & 4.40 \\ 16-A & 5.0 & 0.30\end{array}$

$16-A$

1980 Multilayer

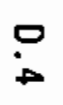

1
5
9
13
12
8
4
16

5.0
10.0
15.0
10.0
8.0
8.0
5.0
7.5
0.16
0.46
0.71
1.20
0.03
0.03
0.24
0.10

2.14
2.14
2.14
2.14
2.14
2.14

10.0

10.0

10.0

10.0

10.0

10.0
1.70
3.50
0.50
4.40
8.70
1.70

2.14

2.14

35.77

2.14

2.14

2.14

1981 Earthen

\begin{tabular}{c} 
Cover \\
\hline 167 \\
166 \\
165 \\
164 \\
163 \\
162 \\
142 \\
143
\end{tabular}

$\begin{array}{rrr}5.0 & 1.06 & 2.14 \\ 5.0 & 1.20 & 2.14 \\ 10.0 & 0.14 & 35.77 \\ 4.0 & 0.10 & 35.77 \\ 4.0 & 0.08 & 35.77 \\ 12.0 & 0.22 & 35.77 \\ 4.0 & 2.15 & 2.14 \\ 4.0 & 1.30 & 2.14\end{array}$

35.77
2.14
2.14
2.14
2.14
2.14
2.14
2.14

10.0

15.0

20.0

15.0

15.0

15.0

10.0

12.5

0.30
0.05

35.77

0.06

2.50

0.14

0.05

1.10

0.76

35.77

35.77

2.14

2.14

2.14

2.14

2.14

Cover

2.14

10.0

2.50

2.14

10.0

13.0

0.20

35.77

0.20

0.14

35.77

8.0

0.18

0.30

15.0

8.0

3.80

35.77

35.77

35.77

12.0

3.10

2.14 
TABLE D.3. (contd)

\begin{tabular}{|c|c|c|c|c|c|c|}
\hline Site & $\begin{array}{c}\text { Low Head } \\
(\mathrm{cm})\end{array}$ & $\begin{array}{l}\text { Drop Rate } \\
\text { (cm/min) }\end{array}$ & $\begin{array}{l}\text { Reservoir } \\
\text { Constant }\end{array}$ & $\begin{array}{l}\text { High Head } \\
(\mathrm{cm})\end{array}$ & $\begin{array}{l}\text { Drop Rate } \\
(\mathrm{cm} / \mathrm{min})\end{array}$ & $\begin{array}{l}\text { Reservoir } \\
\text { Constant }\end{array}$ \\
\hline \multicolumn{7}{|c|}{ 1981 Caissons } \\
\hline $\begin{array}{l}\text { E4 } \\
\text { E3 } \\
\text { E2 } \\
\text { E1 } \\
\text { M2 } \\
M 1\end{array}$ & $\begin{array}{l}5.0 \\
4.0 \\
4.0 \\
4.0 \\
4.0 \\
4.0\end{array}$ & $\begin{array}{l}4.7 \\
0.2 \\
2.3 \\
2.8 \\
2.5 \\
2.2\end{array}$ & $\begin{array}{r}2.14 \\
35.77 \\
2.14 \\
2.14 \\
2.14 \\
2.14\end{array}$ & $\begin{array}{r}10.0 \\
8.0 \\
8.0 \\
8.0 \\
8.0 \\
8.0\end{array}$ & $\begin{array}{l}0.62 \\
0.42 \\
5.2 \\
4.7 \\
4.3 \\
4.25\end{array}$ & $\begin{array}{r}35.77 \\
35.77 \\
2.14 \\
2.14 \\
2.14 \\
2.14\end{array}$ \\
\hline \multicolumn{7}{|l|}{ 1981 Asphalt } \\
\hline $\begin{array}{r}129 \\
127 \\
99 \\
87 \\
85 \\
81\end{array}$ & $\begin{array}{r}4.0 \\
8.0 \\
4.0 \\
11.5 \\
3.5 \\
3.5\end{array}$ & $\begin{array}{l}1.18 \\
5.72 \\
1.73 \\
0.42 \\
2.02 \\
1.02\end{array}$ & $\begin{array}{r}2.14 \\
2.14 \\
2.14 \\
35.77 \\
2.14 \\
2.14\end{array}$ & $\begin{array}{r}8.0 \\
12.0 \\
8.0 \\
15.0 \\
8.0 \\
8.0\end{array}$ & $\begin{array}{l}2.66 \\
0.55 \\
3.76 \\
0.61 \\
5.4 \\
2.75\end{array}$ & $\begin{array}{r}2.14 \\
35.77 \\
2.14 \\
35.77 \\
2.14 \\
2.14\end{array}$ \\
\hline \multicolumn{7}{|c|}{ 1981_Multilayer } \\
\hline $\begin{array}{r}62 \\
64 \\
44 \\
47 \\
49 \\
681\end{array}$ & $\begin{array}{l}5.0 \\
5.0 \\
5.0 \\
5.0 \\
5.0 \\
5.0\end{array}$ & $\begin{array}{l}1.28 \\
2.5 \\
2.6 \\
2.0 \\
1.0 \\
1.8\end{array}$ & $\begin{array}{l}2.14 \\
2.14 \\
2.14 \\
2.14 \\
2.14 \\
2.14\end{array}$ & $\begin{array}{l}10.0 \\
10.0 \\
10.0 \\
10.0 \\
10.0 \\
10.0\end{array}$ & $\begin{array}{l}2.35 \\
3.5 \\
4.15 \\
3.87 \\
2.4 \\
3.05\end{array}$ & $\begin{array}{l}2.14 \\
2.14 \\
2.14 \\
2.14 \\
2.14 \\
2.14\end{array}$ \\
\hline
\end{tabular}




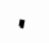




\section{DISTRIBUTION}

No. of

Copies

OFFSITE

10 DOE/Office of Scientific and Technical Information

6 DOE Office of Civilian Radioactive Waste Management Forrestal Building Washington, DC 20585

ATTN: L. H. Barrett, RW-33

C. R. Cooley, RW-40

J. R. Hilley, RW-30

S. H. KaJe, RW-20

D. E. Shelor, RW-32

R. Ste in, RW-23

4 DOE Office of Defense Waste \& Transportation Management GTN

Washington, DC 20545

ATTN: T. C. Chee, DP-123

K. A. Chorey, DP-123

G. H. Daly, DP-124

J. E. Lytie, DP-12

4 DOE Office of Remedial Action GTN

\& Waste Technology

Washington, DC 20545

ATTN: J. A. Coleman, NE-24

T. W. McIntosh, NE-24

W. R. Voight, NE-20

H. F. Walter, NE-24

3 DOE Idaho Operations Office 550 Second Street Idaho FalTs, ID 83401

ATTN: J. P. Hamric

S. T. Hinschberger

J. L. Lyle
No. of

Copies

J. Anderson

DOE-Albuquerque Operations Office

P.0. Box 5400

Albuquerque, NM 87115

W. J. Brumley

DOE Savannah River Operations Office

P.0. Box A

Aiken, SC 29801

F. T. Fong

DOE San Francisco Operations

1333 Broadway

0akland, CA 94612

M. R. Jugan

DOE Oak Ridge Operations Office P.0. BoX E

Oak Ridge, TN 37830

L. Little

DOE, Grand Junction Operations Office

P.0. Box 2567

Grand Junction, CO 81502

E. Maestas

DOE West Valley Project Office

P.0. Box 191

West Valley, NY 14171

J. M. McGough

DOE Albuquerque Operations Office

P.0. Box 5400

Albuquerque, NM 87115 
No. of

Copies

$R$. Senna

DOE-Albuquerque Operations Office

P.0. 5400

A]buquerque, NM 87115

C. S. Abrams

Argonne National Laboratory

P.0. Box 2528

Idaho Falis, ID 83401

K. Agogino

Jacobs Engineering Group

Albuquerque Operations

5130 Central Avenue, N.E.

Suite 1700

Albuquerque, NM 87108

3 Battelle Memorial Institute

Project Management Division

$505 \mathrm{King}$ Avenue

Columbus, $\mathrm{OH} 43201$

ATTN: W. A. Carbeiner

W. S. Madia

Technical Library

J. R. Berreth

West inghouse Idaho

Nuclear Co., Inc.

P.0. Box 4000

Idaho Falls, ID 83401

W. Brewer

Office of High-Level Nuclear Waste Management

Washington State Department of Ecology

Mail Stop PV-11

OTympia, WA 98504

A. T. Clark

Division of Fuel Material Safety

Nuclear Regulatory Commission

Washington, DC 20555

G. A. Dinwiddie

U.S. Geological Survey

12201 Sunrise Valley Drive

Reston, VA 22092
No. of

Copies

T. Dobrowski

UNC Geotech

P.0. Box 14000

Grand Junction, CO 81502

J. Duray

UNC Geotech

P.0. Box 14000

Grand Junction, CO 81502

6 E. I. du Pont de Nemours Company

Savannah River Laboratory

Aiken, SC 29801

ATTN: R. G. Baxter

M. D. Boersma

J. G. Glasscock

J. R. Knight

M. J. Plodinec

C. T. Randa 11

J. Fischer

Low-Level Radioactive Waste Program

U.S. Geological Survey

Water Resources Division

12201 Sunrise Valley Drive

Reston, VA 22092

L. Frank

Department of Energy

625 Marion Street, N.E.

Salem, OR 97310

P. G. Hagan

Joint Integration office

Carlmont Executive 1

4308 Carlisle N.E.

Albuquerque, NM 87107

T. E. Hakonson

Los Alamos National Laboratory

P.0. Box 1663

Los Alamos, NM 87545

E. A. Jennrich

EG\&G Idaho

P.0. Box 1625

Idaho Falls, ID 83415 
No. of

Copies

D. A. Knecht

West inghouse Idaho Nuclear Company

P.0. Box 4000

Idaho Falls, ID 83403

S. Meyers

Environmental Protection Agency

Office of Radiation Programs (ANR-458)

401 M Street S.W.

Washington, DC 20460

4 Oak Ridge National Loaboratory

P.0. Box Y

Oak Ridge, TN 37830

ATTN: J. 0. Blomeke

W. D. Burch

R. T. Jubin

L. J. Mezga

D. T. Oakley, MS 619

Los A] amos Scientific Laboratory

P.0. Box 1663

Los Alamos, NM 87544

E. O'Donnel1

Nuclear Regulatory Commission

MS-NLS-260

Washington, DC 20555

L. D. Ramspott

Lawrence Livermore Nationa] Laboratory

University of California

P.0. Box 808

Livermore, CA 94550

J. Rense]

High-Level Waste Management

Washington State Department of Ecology

Mail Stop Pu II

Olympia, WA 98504

2 Sandia Laboratories

P.0. Box 5800

Albuquerque, NM 87185

ATTN: R. W. Lynch

Technical Library
No. of

Copies

\section{R. Shaw}

Electric Power Research Institute

3412 Hillview Avenue

P.0. Box 10412

Palo Alto, CA 94304

M. J. Steindler

Argonne National Laboratory

9700 South Cass Avenue

Argonne, IL 60439

V. Stello

Office of the Executive

Director for Operations

Mail Station 6209

Nuclear Regulatory Commission

Washington, DC 20555

L. Stepp

Jacobs Engineering Group

Albuquerque Operations

5301 Central Ave. N.E.

Sujte 1700

A7buquerque, NM 87108

5 West Valley Nuclear Services Company

P.0. Box 191

West Valley, NY 14171

ATTN: C. C. Chapman

J. C. Cwynar

J. E. Krauss

S. J. Marchette

J. M. Pope

J. L. White, Chairman

Energy Research \& Development Authority

Empire State Plaza

Albany, NY 12223 
No. of

Copies

ONSITE

8 DOE Richland Operations Office

G. J. Bracken

J. J. Broderick

R. D. Freeburg

R. E. Gerton

R. D. Izatt

G. H. Rosenwald

J. P. Sands

J. J. Sutey

25 Westinghouse Hanford Company

M. R. Adams

L. C. Brown

J. W. Cammann

R. A. Carlson

H. F. Daugherty

K. A. Gasper

W. F. Heine

J. M. Henderson

G. W. Jackson

K. N. Jordan

D. S. Landeen

R. E. Lerch

H. E. McGuire

K. W. Owens

K. L. Petersen

S. J. Phillips

J. F. Relyea

R. C. Roos

R. C. Routson

W. W. Schulz

S. A. Weigman

N. R. Wing

D. D. Wodrich

R. D. Wojtasek

D. E. Wood
No. of

Copies

43 Pacific Northwest Laboratory

L. L. Cadwell

M. D. Campbelt (3)

J. H. Cary

J. F. Cline

J. L. Downs

J. W. Falco

M. J. Fayer

M. G. Foley

H. D. Freeman (3)

G. W. Gee (5)

M. J. Graham

J. M. Hales

P. C. Hays

T. L. Jones

C. T. Kincaid

R. R. Kirkham

G. V. Last

M. W. Ligotke

S. 0. Link

W. H. Rickard

L. E. Rogers

R. L. Skaggs

J. A. Stottlemyre

G. P. Streile

J. M. Thomas

R. L. Treat

W. J. Waugh

S. G. Weiss

R. E. Wildung

Publishing Coordination

Technical Report Files (5) 